\title{
Early Stage Glycosylation Biomarkers in Alzheimer's Disease
}

\author{
Patricia Regan 1,2,*, Paula L. McClean ${ }^{3}$, Thomas Smyth ${ }^{1,2}$ and Margaret Doherty ${ }^{1,2}$ \\ 1 Institute of Technology Sligo, Ash Lane, F91 YW50 Sligo, Ireland \\ 2 Cellular Health and Toxicology Research Group, Institute of Technology Sligo, Ash Lane, \\ F91 YW50 Sligo, Ireland \\ 3 Northern Ireland Centre for Stratified Medicine, Biomedical Sciences Research Institute, Clinical \\ Translational Research and Innovation Centre, Altnagelvin Area Hospital, Glenshane Road, \\ Derry BT47 6SB, UK \\ * Correspondence: Patricia.Regan@mail.itsligo.ie; Tel.: +353-(0)-71-91-55320
}

Received: 30 June 2019; Accepted: 30 August 2019; Published: 3 September 2019

\begin{abstract}
Alzheimer's disease (AD) is of great cause for concern in our ageing population, which currently lacks diagnostic tools to permit accurate and timely diagnosis for affected individuals. The development of such tools could enable therapeutic interventions earlier in the disease course and thus potentially reducing the debilitating effects of AD. Glycosylation is a common, and important, post translational modification of proteins implicated in a host of disease states resulting in a complex array of glycans being incorporated into biomolecules. Recent investigations of glycan profiles, in a wide range of conditions, has been made possible due to technological advances in the field enabling accurate glycoanalyses. Amyloid beta $(\mathrm{A} \beta)$ peptides, tau protein, and other important proteins involved in $\mathrm{AD}$ pathogenesis, have altered glycosylation profiles. Crucially, these abnormalities present early in the disease state, are present in the peripheral blood, and help to distinguish AD from other dementias. This review describes the aberrant glycome in AD, focusing on proteins implicated in development and progression, and elucidates the potential of glycome aberrations as early stage biomarkers of AD.
\end{abstract}

Keywords: Alzheimer's; biomarker; glycosylation; $\mathrm{A} \beta$; tau

\section{Introduction}

\subsection{Alzheimer's Disease (AD)—A Cause for Concern}

There are currently over 50 million cases of dementia in the world, of which AD is the predominant form, possibly making up 60-70\% of cases [1,2]. Development of AD is related to advanced age and, as life expectancy increases, it is expected that AD cases will increase four-fold by the year 2050 [3,4]. Sufferers of the disease experience deterioration of memory and cognition, which slowly worsens as the disease progresses until they are eventually unable to care for themselves [5]. From initial diagnosis, death typically occurs after $8-10$ years [6].

\subsection{AD Pathogenesis}

$\mathrm{AD}$ is characterised by the formation of plaques composed of amyloid beta $(\mathrm{A} \beta)$ peptides, which are formed from abnormally processed amyloid precursor protein (APP) protein, and the presence of neurofibrillary tangles derived predominantly from hyperphosphorylated tau protein, in the brain [7]. Hyperphosphorylated tau (AD P-tau) aggregates, causing paired helical filaments (PHFs) to form, accumulation of which leads to neurofibrillary tangle formation [8]. Intraneuronal tau and extraneuronal amyloid plaques, contribute to neuronal cell death and loss of synaptic function $[9,10]$. 
Neurofibrillary tangles progressively spread from the entorhinal cortex to other parts of the brain such as the hippocampus and cerebral cortex, and these brain regions are associated with significant neuronal loss and physical shrinkage [11-13]. The cortex and hippocampus are strongly associated with cognition, thought, memory, learning and awareness [14,15]. Hippocampal atrophy is severe and has been used as a diagnostic and prognostic marker of AD [16,17]. Earlier diagnostic markers in these brain regions would be invaluable.

\subsection{Treatments for $A D$ and the Urgency of An Early Diagnosis}

A deficit in the cholinergic system is a major characteristic of $\mathrm{AD}$ [18]. $\mathrm{AD}$ treatments currently available aim to correct the altered neurotransmission, but these are symptomatic as the individual will still eventually succumb to the disease $[19,20]$. Disease modifying treatments under investigation aim to reduce $\mathrm{A} \beta$ plaque formation by inhibition or modulation of secretases involved in the amyloid pathway [21,22], or increase $A \beta$ clearance by immunological approaches $[23,24]$. Immunological removal of tau aggregates is also under investigation [25], in addition to prevention of tau hyperphosphorylation using kinase inhibitors, as kinases induce the hyperphosphorylation of tau $[26,27]$. However, the success of interventions in clinical trials has been very poor to date $[28,29]$. To compound matters, often current treatments are only significantly effective in mild AD sufferers, but not in moderate AD sufferers [30,31]. There is therefore a critical need to diagnose patients as early as possible so that they may derive maximum benefit from existing therapies and initiate disease modifying therapies, when they become available, as early in the disease course as possible.

\subsection{AD Diagnosis-Invasive and Inconclusive}

Aside from advanced age, the apolipoprotein E4 gene is the biggest risk factor for late onset AD; some $64 \%$ of sporadic AD sufferers and $80 \%$ of familial AD sufferers have at least one copy of the gene [32]. Mutations in APP, presenilin (PS)1 and PS2 genes almost guarantee that an individual will develop early onset AD, which occurs before 65 years of age [33]. However, early onset AD accounts for only $1-2 \%$ of AD cases [34].

At present, AD is routinely diagnosed via cognitive and learning assessments, however, this merely identifies AD as the most probable cause of symptoms which have presented. Distinguishing AD from other types of dementias is difficult as memory-related symptoms and physical changes in the brain are also observed in other neurodegenerative disorders, as well as in the normal, ageing brain [35-38]. Characteristic whole-brain and hippocampal tissue atrophy seen in AD [11] is identified using magnetic resonance imaging (MRI) and computed tomography (CT) [39], however, this atrophy is present in other forms of dementia [40-42]. Post mortem identification of pathological defects in the AD brain is necessary for definitive diagnosis [43].

Positron emission tomography (PET) is another imaging technique which uses radiotracers of biomarkers in an AD diagnosis [44]. 2-[18F]fluoro-2-Deoxy-D-glucose (FDG) is a common PET tracer which identifies the reduction of cerebral metabolic rates of glucose (CMRglc) seen in AD [45]. However, this disturbed CMRglc metabolism is seen in other types of dementias, making it non-specific to the disease state [46]. PET tracers of A $\beta$ peptides, such as Pittsburg compound B, have emerged which bind specifically to amyloid plaques in the brain [47]. However, it appears that $A \beta$ plaque formation does not correlate directly with cognitive decline [48], making it unreliable as a disease progression indicator. Promising tau-specific PET tracers have recently been developed but will require further clinical validation studies [49].

The difficulties in AD diagnosis indicates a significant clinical need to develop non-invasive diagnostic tests, ideally from peripheral blood. The popular approaches to biomarker testing today are costly neuroimaging, as discussed, and cerebrospinal fluid (CSF) analysis. CSF may be assessed for elevated total tau and AD P-tau levels, and decreased $\mathrm{A} \beta$ peptide levels, which requires patients to undergo a painful lumbar puncture [50]. As this review will explore, there are many reported changes in the AD glycome occurring early in the disease pathogenesis, many of which are present in 
the periphery and could be exploited as biomarkers of AD. Before these changes are discussed, it is important to understand glycosylation and the role it plays in human health and disease.

\section{Glycosylation Overview}

\subsection{What is Glycosylation?}

Glycosylation is an enzymatic process where glycosyltransferase enzymes use activated sugar donor molecules to attach monosaccharides to growing glycans via a glycosidic linkage [51-53]. Glycosidases and glycosyltransferases, involved in the synthesis of glycans, are each specific to a particular sugar and to their type of linkage [54,55]. N- and O-linked glycosylation are the most common types of protein glycosylation. O-linked glycans are linked to the hydroxyl group of threonine or serine in a protein, whereas N-linked glycans are linked to the nitrogen atom of an asparagine residue [56,57]. However there is no site specific addition of O-glycans to serine or threonine residues and the core structure of an O-glycan is variable, therefore O-glycan synthesis is not always initiated by the same glycosyltransferase [58]. The focus of this review is on N-glycans which are present in $90 \%$ of glycoproteins [59], are the most characterised of all glycans and strongly implicated in the AD pathogenesis [60-64]. A single enzyme known as oligosaccharyltransferase initiates glycan synthesis in the N-linked pathway. All N-glycans have a common core, and oligosaccharyltransferase specifically catalyzes the addition of the growing $\mathrm{N}$-glycan to asparagine at the sequences asparagine- $\mathrm{X}$-serine or asparagine- $X$-threonine, $X$ being any amino acid except proline [52]. The synthesis of $\mathrm{N}$-glycans begins in the endoplasmic reticulum and continues into the Golgi, occurring co- and post-translationally [52,65]. $\mathrm{N}$-glycans may be either high mannose, complex or hybrid types depending on the additional sugar modifications extending from their core structure of two N-acetyl glucosamine (GlcNAc) monosaccharides and three mannoses [66-69].

\subsection{Approaches to Glycoanalysis}

Glycans may be analysed after cleavage from the respective protein, or glycoproteins may be analysed intact [70]. N-glycan cleavage may be achieved chemically by hydrazinolysis [71] or enzymatically by peptide-N4-(N-acetyl- $\beta$-glucosaminyl) asparagine amidase, typically known as PNGase F, digestion which cleaves glycans at asparagine residues, the exclusive site of N-glycosylation [72]. Since the attachment sites of glycans to the peptide backbone are different depending on the type of glycosylation, there is no single method which may be used to cleave glycans from the respective glycoproteins. Liquid chromatography (LC), porous graphitic carbon chromatography (PGC), and capillary electrophoresis are commonly used chromatographic separation methods for released glycan analysis [73].

Glycans are typically fluorescently labelled prior to LC analysis as they lack natural chromophores [74]. Hydrophilic interaction LC offers the advantage of identifying structural isomers as well as determining linkage information in some cases, which other LC modes cannot [75]. Weak anion exchange high performance liquid chromatography (HPLC) is sometimes used as an orthogonal method for the separation of similar glycans or those containing negatively charged sialic acids [76]. Databases such as GlycoStore have been established to give information related to the separated glycan structures [77].

The advent of ultra-high performance liquid chromatography (UPLC) and sub-2 $\mu$ m particle size columns has permitted quicker separation and improved separation capacity [78-80]. Separation of glycan mixtures is still difficult because isomeric glycans, that are commonly present [81], will co-elute. Exoglycosidase sequencing is therefore often used to delineate isomeric glycans identified by the initial separation, while also providing conclusive linkage information of the monosaccharides present [82-84]. Figure 1 illustrates a typical N-glycan profiling approach employing PNGase F digestion, fluorescent labelling, exoglycosidase sequencing and UPLC analysis of a glycoprotein mixture. 


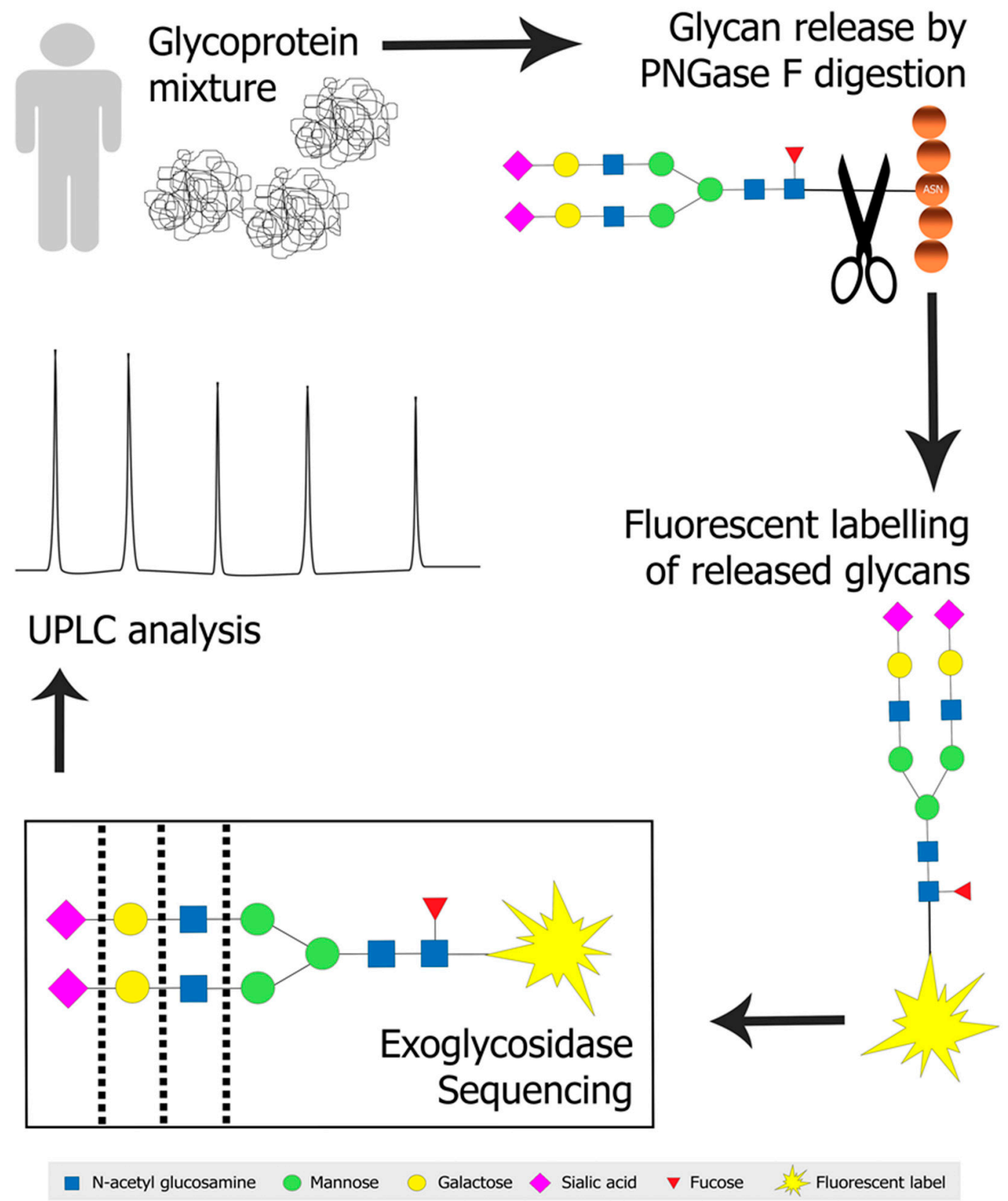

Figure 1. N-glycan profiling of a glycoprotein mixture. N-linked glycans are cleaved from glycoproteins by PNGase F digestion and fluorescently labelled in preparation for exoglycosidase sequencing and subsequent ultra-high performance liquid chromatography (UPLC) analysis. Terminal monosaccharides are removed from the non-reducing end of a glycan structure during an exoglycosidase digestion. Black dotted lines indicate the points of enzymatic digestion in this example of an exoglycosidase digestion. ASN, Asparagine residue in a protein chain; UPLC, ultra high performance liquid chromatography; PNGase F, peptide-N4-(N-acetyl- $\beta$-glucosaminyl) asparagine amidase. Images were created using Adobe Photoshop.

Lectins are commonly employed in glycoprofiling studies [85-87] and are useful in the analysis of intact glycoproteins, as well as the localisation of these glycoproteins in cells and tissues [88,89]. Mass spectrometry (MS) is another widely used and accurate method to analyse glycan structure without derivatization, which allows for analysis of intact glycoproteins [90]. MS is often used as an orthogonal technique in LC/MS or LC/MS-MS, to give an overall comprehensive analysis of glycoproteins by providing greater separation of structural or geometric glycan isomers [91-94], in addition to confirming 
structural linkages identified using exoglycosidase approaches [95,96]. Nuclear magnetic resonance spectroscopy is another excellent method for detailed structural analysis of glycans, but requires a relatively large quantity of purified glycans [70].

\subsection{Glycosylation and Disease}

N-glycans are vital for a multicellular organism's survival [97,98]. Glycoproteins are on the extracellular surface of the plasma membrane, the extracellular matrix of cells, and are also secreted into bodily fluids. Almost all proteins in human serum and on mammalian cell membranes are glycosylated [59]. Glycans ensure proper protein folding, trafficking, and functionality in addition to facilitating cell signaling and cell-cell communication [99-101]. Changes in the physiological state may alter glycans found on glycoproteins at the same location [102,103]. Glycosylation changes also occur in many disease states. Changes in glycosylation patterns is a hallmark of cancer [104]. Breast [105], stomach [106], and liver [107] cancers all have altered serum glycoprofiles. Rheumatoid arthritis is associated with reduced IgG galactosylation and sialic acid termini [108]. Congenital disorders of glycosylation (CDGs) are a group of illnesses caused by aberrant glycosylation rooted in genetic defects in the enzymes and biomolecules involved in glycan synthesis. Over 100 CDGs exist, common examples being ALG1-CDG, PMM2-CDG and MPI-CDG, each named after the defective gene in the respective CDG [109]. Such disorders result in symptoms affecting multiple organs, commonly the brain and nervous system, due to the far reaching impact of glycosylation on the functionality of the human proteome $[110,111]$.

\section{Glycosylation and AD}

\subsection{Glycosylation of Proteins Implicated in $A D$ in the Brain}

Glycosylation has been implicated in AD pathology in many studies. Numerous changes have been detected in the AD brain. Immunoprecipitation and lectin blotting of $\beta$-site APP-cleaving enzyme 1 (BACE1), the N-glycosylated enzyme [112] responsible for the toxic $\beta$-secretase cleavage of APP [113], from the brains of AD patients revealed increased levels of bisecting GlcNAc, and crucially this increase was observed in both early and late stage patients [112]. A later study found that this increase in bisecting GlcNAc on BACE1 stabilises the protein under oxidative stress conditions [114], a feature characteristic of AD pathology [115].

APP is modified with O-GlcNAc [116] and studies have indicated that the mucin-type O-glycosylation of APP has a negative impact on $A \beta$ production $[117,118]$. One of these studies revealed an increase in expression levels of transferases responsible for this mucin-type O-glycosylation in the early and late stage AD brain versus non-AD controls through quantitative real-time polymerase chain reaction (RT-PCR) analysis of human brain tissue [117]. N-acetylglucosaminyltransferase III (GnT-III) is the glycosyltransferase responsible for adding bisecting GlcNAc [119]. RT-PCR analysis of GnT-III mRNA revealed an increase in its expression in AD patient brains [119].

Findings suggest N-glycosylation occurs before hyperphosphorylation of tau, where non-hyperphosphorylated tau in AD brain exhibited N-glycan specific lectin staining versus an observed absence of this in normal tau in healthy controls [120]. In fact glycosylation of tau may induce hyperphosphorylation as the N-glycosylated form of the protein proved to be a better substrate for kinase than its native form [120]. The N-glycans found on phosphorylated tau and PHFs also differ, with more truncated glycans found on PHF-tau, identified in human AD brain tissue using complimentary analyses by HPLC, exoglycosidase digestions and MS [121].

Polysialylated neural cell adhesion molecule (PSA-NCAM) is recognized for its role in central nervous system development but is also reported to function in the connectivity of interneurons in the adult cerebral cortex [122]. A study revealed significantly decreased immunostaining of PSA-NCAM in the entorhinal cortex of AD brain tissue taken post mortem, relative to healthy controls. The same study found the decrease in PSA-NCAM load in the AD entorhinal cortex to be inversely proportional 
to hyperphosphorylated tau load [123]. This indicates a reduction in PSA-NCAM load specific to a brain region known to be severely affected in the AD pathogenesis [11-13], and shows that this change is potentially related in some way to increases in hyperphosphorylated tau load. Despite these findings, the identification of glycosylation changes in the AD brain is clearly not diagnostically viable.

\subsection{Glycosylation Biomarkers of $A D$ in the CSF and Blood}

A study of the glycosylation changes in both pre-dementia and AD patient CSF using matrix-assisted laser desorption/ionization-MS showed an increase in bisect type N-glycans and a decrease in sialylated species in both pre-dementia and AD cases, indicating that AD related glycosylation changes occur before clinical symptoms manifest [124].

Detection of alterations in the AD glycome via peripheral serum and plasma would be advantageous diagnostically, given the invasive nature of CSF sampling. An obstacle in the analysis of serum is that many brain derived proteins are not present in the blood due to their inability to cross the blood brain barrier [125]. However, the N-glycoprofiles of a mouse model of neurodegeneration revealed decreases in specific glycans in the serum and cerebral cortex, and the changes correlated to learning and memory deficiencies [126]. In humans, AD patient serum exhibited increased bisect-type and highly branched glycoforms in a study which employed glycoblotting and MS analysis of patient serum samples [127]. The same study similarly showed an increase in these particular species of glycan in AD patient CSF versus non-AD controls [127]. Of note, bisect type glycans are atypical of serum, but are common "brain-type" glycans [128]. Reduced sialyltransferase activity has been observed in AD patient serum using a radio-enzymatic assay [129]. It is interesting to note that the gene for a sialic acid binding receptor, known as Siglec 33, is implicated in late-onset AD [130].

Sera levels of a bi-galactosylated core fucosylated bi-antennary glycan were shown to decrease with age in a study employing a glycoanalytical tool known as DNA sequencer-assisted, fluorophore-assisted carbohydrate electrophoresis (DSA-FACE) [131]. However, in another study employing DSA-FACE, sera levels of the same glycan were shown to decrease significantly more in AD patients in comparison to healthy controls and could additionally distinguish AD patients from other non-AD patients [132]. This is significant from a diagnostic standpoint, due to the difficulty in distinguishing AD from other neurodegenerative disorders, if it could be identified in a clinical setting using a higher throughput approach.

O-glycan changes in AD are widely reported [133-140]. Recently it was observed that neuroinflammation induced by $\mathrm{A} \beta$ modifies mucin-type O-glycosylation in rat hippocampus, which was observed by injection of $A \beta$ into rat brain hippocampus followed by lectin analysis [141]. Interestingly, $\mathrm{A} \beta$ immunopurified from $\mathrm{AD}$ and non-AD CSF revealed a unique O-glycosylation of a specific tyrosine residue upon LC-MS/MS analysis, and the ratio of this tyrosine glycosylation in $A \beta$ to the respective unglycosylated form was found to be up to 2.5 times more prevalent in the CSF of the AD patients compared to healthy and non-AD controls [142]. Aside from these general glycomic changes at play, glycosylation changes have been observed in all of the major AD related proteins, and crucially some changes are occurring at early stages in the disease state [60-62].

\subsection{The Direct and Indirect Impact of BACE1 Glycosylation in AD Pathology}

Cleavage of APP in neurons by $\alpha$-secretase followed by $\gamma$-secretase yields a soluble peptide under normal physiological conditions [143]. Soluble APP has neuroprotective functions against excitotoxicity [144] and $A \beta$ toxicity [145] in neurons. In AD, $\beta$-secretase and $\gamma$-secretase cleave APP sequentially, resulting in the formation of toxic $A \beta$ peptide [146]. As stated previously, BACE1 is the enzyme responsible for the toxic $\beta$-secretase cleavage of APP [113] and is N-glycosylated [112]. Alteration of N-glycosylation sites in aspartyl protease 2, now known to be BACE1, was shown to reduce its proteolytic activity [147]. GnT-III knockout in mice resulted in reduced A $\beta$ deposition and improved short term memory [112]. It therefore appears that aberrant N-glycosylation of BACE1 has a direct role in AD pathology. $\beta$-secretase additionally functions in protein glycosylation, specifically 
in cleaving sialyltransferases [148,149]. An in vitro study where a particular sialyltransferase was overexpressed in order to induce increased sialylation of APP, resulted in increased production of $A \beta$ peptides [150]. Another in vitro study showed that overexpression of BACE1 enhances sialylation of soluble secreted glycoproteins through lectin analysis [151]. Elucidating the effects of BACE1 on the glycoprofiles of specific AD related glycoproteins may make its role more clear in the AD pathology.

\subsection{APP Glycans as Protective Mechanisms in AD}

Several studies indicate that APP sorting, secretion, transport and localisation are affected by its N-glycosylation [150,152-154]. Therefore glycoforms of this major AD related protein are likely to have a significant effect on the pathology of the disease. An in vitro study where mouse neuroblastoma cells were transfected with either wild-type APP or APP mutants related to AD, revealed increased levels of bisecting GlcNAc and core fucose N-glycan alterations on APP mutants compared to wild-type APP upon analysis of isolated glycans by HPLC [155]. GnT-III may act as a protective mechanism in the presence of amyloid plaques, as a study additionally revealed a decrease in A $\beta$ production in GnT-III transfected mouse neuroblastoma cells when $A \beta$ concentrations in culture supernatants were determined using enzyme-linked immunosorbent assay (ELISA). What is more, an increased activity of the neuroprotective $\alpha$-secretase was also observed in GnT-III transfected cells [119]. A disintegrin and metalloproteinase 10 (ADAM10) is the major $\alpha$-secretase in neurons responsible for normal, non-amyloidogenic cleavage of APP [156]. ADAM10 is key to neurodevelopment [157] and synaptic plasticity [158]. It interacts with APP and other proteins, and levels of ADAM10 are reduced in AD patient blood [159]. Although $\mathrm{N}$-glycosylation of this glycoprotein has been shown to be crucial to its functionality by mutation of its second N-glycosylation site in vitro which caused both reduced enzymatic activity and proteolytic activation [160], its glycoprofile in AD remains elusive and warrants investigation.

\subsection{Tau Phosphorylation is Directed by its Glycosylation}

A disruption to O-GlcNAc modification of proteins in AD has been reported [134-140]. Tau is ordinarily O-glycosylated by single GlcNAc residues [161]. Tau protein is involved in microtubule assembly and stabilisation [162], and is hyperphosphorylated in AD [163,164]. Decreased wheat germ agglutinin (WGA) lectin blotting of tau was observed in phosphatase-inhibited human neuroblastoma cells [165]. WGA is a lectin with a high affinity for GlcNAc [166]. This indicates that hyperphosphorylation of tau, which is characteristic of $\mathrm{AD}$, results in downregulation of O-linked tau glycans. As O-linked glycans attach to threonine or serine, they occupy the principal sites of phosphorylation [167]. Another study where decreased O-GlcNAcylation of tau was induced by glucose starvation of mice to mimic AD pathology resulted in increased phosphorylation of tau upon western blot analysis. This indicates that O-GlcNAcylation acts as a protective mechanism against hyperphosphorylation of tau in $\mathrm{AD}$, and that the impaired glucose metabolism may be causing the reduced O-GlcNAc modification of proteins [168].

It appears that tau N-glycans are key to the stabilisation of PHF structures. The dephosphorylation and deglycosylation of tau in PHF structures increased the release of tau and restored its microtubule polymerization activity, further implicating the role of tau N-glycans in AD [169]. Tau is normally a cytosolic protein [170] and because N-glycosylation normally only occurs in secreted or membrane bound proteins [171], this may indicate a subcellular relocation of tau in AD pathogenesis.

\subsection{Presenilin and Transmembrane Protein 59 (TMEM59) are Regulators of Protein Glycosylation}

$\gamma$-secretase is partly composed of the protein presenilin [172]. Mutations in PS1 and PS2 genes are associated with early onset familial AD [33]. Acetylcholinesterase (AChE) is known to complex with presenilin, and a study conducted in transgenic mice with a PS1 mutation revealed altered mannose termini and disturbed maturation of AChE, indicating PS1 affects AChE functionality [86]. Nicastrin is the only protein in the $\gamma$-secretase complex that is N-glycosylated [173,174], and presenilin knockout cells revealed a reduction in nicastrin $\mathrm{N}$-glycosylation and maturation [175]. An in vitro study where 
AD-related PS1 was overexpressed in a human neuroblastoma cell line identified a reduction in sialylation of neural cell adhesion molecule (NCAM) using lectin analysis [176].

TMEM59 expression is increased in late-onset AD [177]. An in vitro study showed that TMEM59 expression affects Golgi localised complex glycosylation, reducing galactosylation and sialylation of key AD related proteins such as APP, BACE1 and nicastrin using western blot analysis. The study also showed that $\alpha$ - and $\beta$-secretase shedding of APP and APP cell surface expression were both suppressed by TMEM59 expression [178]. These findings indicate that presenilin $[86,175,176]$ and TMEM59 [178] regulate protein glycosylation. Further study of the effects of abnormal presenilin and upregulated TMEM59 on relevant glycoproteins may be worth investigation.

\subsection{Apolipoprotein Glycosylation Changes in $A D$}

Clusterin, also known as apolipoprotein J (ApoJ), is known to be associated with AD pathogenesis [179] and increased levels of clusterin are present in AD patient blood [180]. Specific glycans on clusterin were decreased in abundance in AD patients with high hippocampal atrophy relative to those with low hippocampal atrophy, analysed using LC-MS/MS analysis [181]. Apolipoprotein D (ApoD) has been shown to modulate amyloid pathology in an AD mouse model [182]. ApoD in human plasma is $\mathrm{N}$-glycosylated [183]. Overall the N-glycoprofiles of the different apolipoproteins have not been investigated in detail and may be worth exploring given the indicated implications this group of proteins have in AD pathology.

\subsection{AD-Associated Glycosylation Changes to Transferrin are Different in CSF to Serum}

Increased iron concentration and disturbed iron metabolism are associated with AD [184,185]. Transferrin was identified from AD patient CSF as having reduced sialic acid termini present by lectin binding analysis and isoelectric focusing, confirmed by comparable levels of transferrin in the CSF of AD patients and controls. Combination of the reduced transferrin lectin binding with phosphorylated tau ELISA detection, this biomarker was determined to be highly specific and sensitive at distinguishing AD from other dementias [186]. Conversely, transferrin sialylation was found to be increased in AD patient serum using isoelectric focusing and immunoblotting [187]. As such, the glycoprofile of transferrin in AD appears to be altered differently in the periphery to the central nervous system.

\subsection{Other Glycoproteins Associated with AD Pathology}

Glycosylation is further implicated in other proteins associated with AD pathology. Acetylcholine has various functions in the nervous system, one of which is related to short term memory and learning [188]. A deficit in acetylcholine is associated with AD [189]. Several studies indicate glycoforms of AChE may present early in the disease state [190,191], however, conflicting findings indicate that the changes are in fact not present at early stages [192], meaning it may not be reliable early marker of AD. Reelin is a glycoprotein found in the extracellular matrix which has a role in maintaining synaptic plasticity and can reverse $A \beta$ synaptic dysfunction [193]. It is involved in embryonic brain development [194] and adult brain functionality [195]. A change in mannose specific lectin binding to reelin has been seen in AD patient CSF in comparison to controls [196]. Neprilysin is a metalloproteinase [197] which is known to break down $A \beta$ in the brain [198]. Neprilysin expression is downregulated in AD [199], and mutation of the N-glycosylation sites of neprilysin was shown to reduce its activity and cell surface expression [200,201]. The R47H variant of triggering receptor expressed on myeloid cells 2 (TREM2), a transmembrane protein that is reported to be associated with late-onset AD progression [202], was recently found to have an altered N-glycoprofile in comparison to the wild type. The study determined that the $\mathrm{R} 47 \mathrm{H}$ variant has increased complex oligosaccharide alterations in comparison to the wild type, in addition to reduced stability [203].

A study in which the glycoprofiles of IgG in human blood were assessed using LC-MS/MS analysis revealed significant glycan changes in the $\mathrm{AD}$ group relative to controls, with a lower abundance of 
specific complex galactosylated and sialylated glycans observed in the AD group. Interestingly, the abundance of complex glycans in females reduced steadily from the pre-dementia cases to AD patients, whereas the opposite trend was observed in males just prior to disease onset [204]. The characteristic role of inflammation in AD [205] may explain the observed reduction in sialic acid modification of IgG seen here, as removal of sialic acids from IgG causes a shift in its function from anti-inflammation to pro-inflammation [206]. This is of interest as a readily available marker of AD which is in high abundance in the blood [207], making analyses less complex.

Regarding biomarker discovery, the focus must now turn towards a more comprehensive analysis of the AD glycome, elucidating both the well-known players in the AD pathogenesis in more detail in addition to exploring the lesser known glycoproteins implicated in the AD pathogenesis, as mentioned in this review. Crucially the methods employed should aim to provide a detailed structural analysis of glycan structures and identify their respective proteins, as opposed to the many studies of the AD glycome to date that have popularly employed approaches such as lectin analysis to gain a non-specific insight into the changes at play.

\section{Concluding Remarks}

This review highlights an alteration to the glycan portion of many proteins involved in AD pathogenesis at early stages in the disease state, some examples of which are illustrated in Figure 2. With improved glycoanalytical technologies more readily available, a more detailed and comprehensive analysis of the AD glycome is the appropriate approach in future studies. Table 1 presents promising human AD biomarkers of the CSF and blood that have been reported here. Efforts of future studies should be founded in the analysis of peripheral plasma or serum samples to make glycan biomarkers of $\mathrm{AD}$ a viable diagnostic tool.

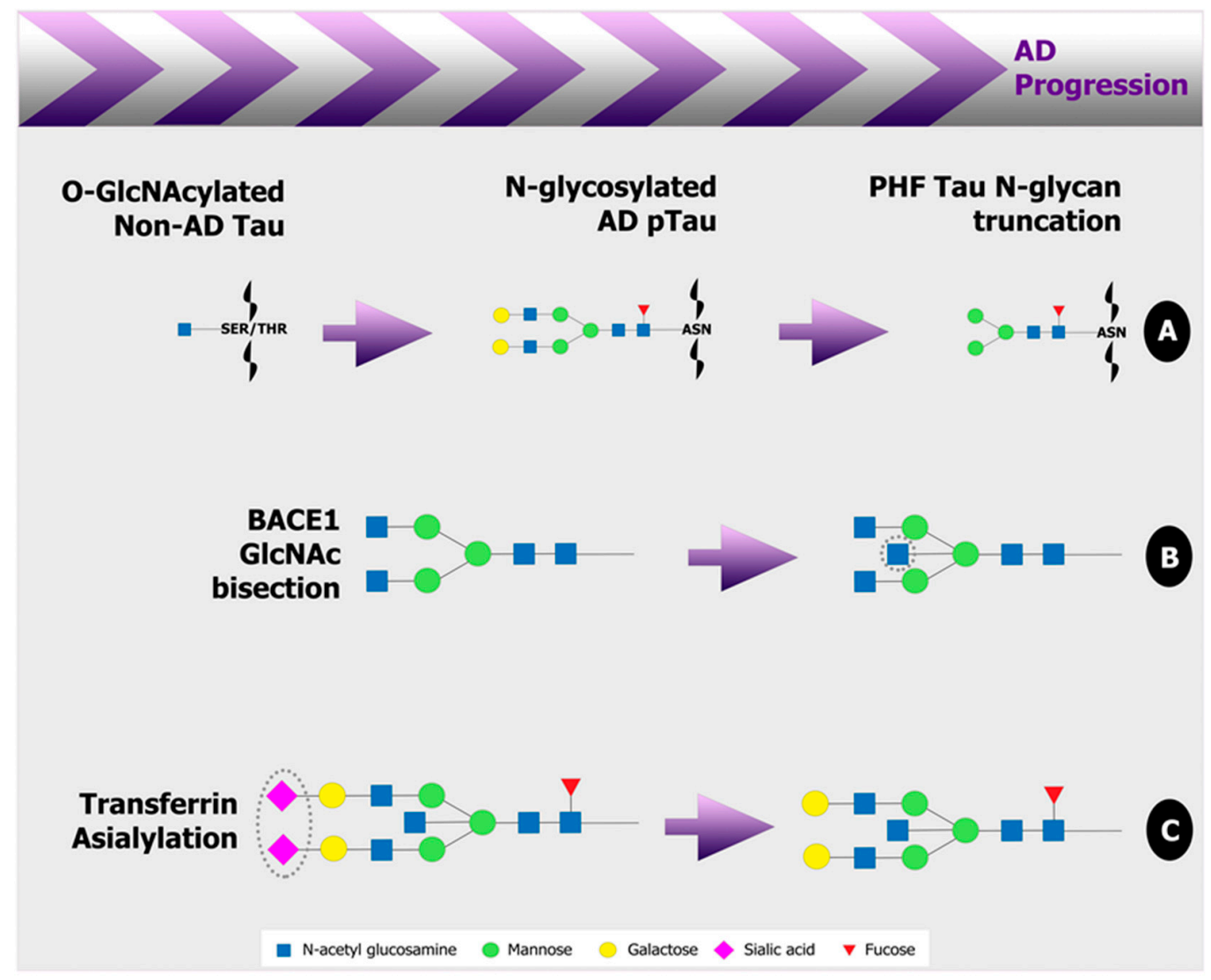

Figure 2. Examples of glycan alterations in disease related glycoproteins in Alzheimer's disease (AD). (A) Tau, a central protein in the AD pathology, is O-GlcNAcylated which acts as a defense against hyperphosphorylation. In $\mathrm{AD}, \mathrm{O}$-glycosylation is downregulated and tau becomes uncharacteristically 
$\mathrm{N}$-glycosylated. Both normal and hyperphosphorylated tau contain N-glycans in AD. Truncated glycans are more abundant on paired helical filaments (PHF) which are present later in the disease pathology. (B) Bisecting GlcNAc on $\beta$-secretase $\beta$-site APP-cleaving enzyme 1 (BACE1) occurs prior to toxic $A \beta$ formation in AD. In contrast, GlcNAc bisection on amyloid precursor protein (APP) stimulates $\alpha$-secretase production and acts as a protective mechanism against amyloid beta (A $\beta$ ) peptide formation (not shown). (C) Decreased terminal sialic acids are present on AD cerebrospinal fluid (CSF) glycoproteins, the major glycoprotein being transferrin which is critical to the survival of neuronal cells. Additionally, BACE1 and presenilin, a subunit of $\gamma$-secretase, both have a direct role in the sialylation of AD relevant proteins. Grey dotted lines indicate location of changes on glycan structures. Alzheimer's disease, AD; N-acetyl glucosamine, GlcNAc; amyloid beta, A $\beta$; amyloid precursor protein, APP; cerebrospinal fluid, CSF; $\beta$-site APP-cleaving enzyme 1, BACE1; SER, serine; THR, threonine; ASN, asparagine; pTau, hyperphosphorylated tau; PHF, paired helical filaments. Images were created using Adobe Photoshop.

Table 1. Candidate human biomarkers of glycosylation in AD blood and CSF.

\begin{tabular}{|c|c|c|c|c|}
\hline Location & $\begin{array}{l}\text { Analysis } \\
\text { Method }\end{array}$ & Biomarker & Cohorts & Additional Comments \\
\hline $\begin{array}{l}\text { Serum and } \\
\text { CSF }\end{array}$ & $\begin{array}{c}\text { Glyco-blotting } \\
\text { and MS }\end{array}$ & $\begin{array}{l}\text { Increased bisect type, } \\
\text { core fucosylated, } \\
\text { highly branched } \\
\text { species [127]. }\end{array}$ & $\begin{array}{l}\text { AD patients }(n=2-3) \\
\text { versus sex-matched } \\
\text { non-AD controls } \\
\quad(n=2-3)\end{array}$ & \\
\hline Serum & $\begin{array}{l}\text { Radio-enzymatic } \\
\text { assay }\end{array}$ & $\begin{array}{l}\text { Decreased } \\
\text { sialyltransferase } \\
\text { activity [129]. }\end{array}$ & $\begin{array}{l}\text { AD patients }(n=12) \\
\text { versus age and sex } \\
\text { matched non-AD } \\
\text { controls }(n=12) .\end{array}$ & $\begin{array}{c}\text { Although both moderate } \\
\text { and severe AD cases were } \\
\text { assessed, there was no } \\
\text { correlation between serum } \\
\text { sialyltransferase activity } \\
\text { and degree of AD. } \\
\text { Considerable variation in } \\
\text { the control group was } \\
\text { observed. }\end{array}$ \\
\hline Serum & DSA-FACE & $\begin{array}{c}\text { Decreased } \\
\text { bi-galactosylated core } \\
\text { fucosylated } \\
\text { bi-antennary glycan } \\
\text { [132]. }\end{array}$ & $\begin{array}{c}\text { Population of } \\
\text { primarily } \\
\text { moderate/severe AD } \\
\text { patients }(n=48) \text { versus } \\
\text { age and sex matched } \\
\text { healthy }(n=149) \text { and } \\
\text { non-AD }(n=31) \\
\text { controls. }\end{array}$ & $\begin{array}{c}\text { Desialylated serum } \\
\text { assessed. Difference not } \\
\text { observed between non-AD } \\
\text { patients and age and sex } \\
\text { matched controls. } \\
\text { Discriminated AD patients } \\
(n=48) \text { from non-AD } \\
\text { patients and healthy } \\
\text { controls ( } n=180 \text { ) with a } \\
\text { diagnostic accuracy of } \\
85.7 \% \pm 2.8 \%, 92 \% \\
\text { specificity and } 70 \% \\
\text { sensitivity. }\end{array}$ \\
\hline CSF & $\begin{array}{l}\text { Matrix-assisted } \\
\text { laser de-sorption/ } \\
\text { ionization-MS }\end{array}$ & $\begin{array}{l}\text { Increased bisect type } \\
\text { species and decreased } \\
\text { sialylated species [124]. }\end{array}$ & $\begin{array}{l}\text { Pre-dementia }(n=11) \\
\text { and sporadic AD } \\
(n=24) \text { cases versus } \\
\text { age matched healthy } \\
\text { controls }(n=21) .\end{array}$ & $\begin{array}{l}40-50 \% \text { of the diseased } \\
\text { patients had this altered } \\
\text { glycoprofile versus } \\
\text { controls. All pre-dementia } \\
\text { cases that converted to AD } \\
\text { displayed an altered } \\
\text { glycoprofile. }\end{array}$ \\
\hline CSF & LC-MS/MS & $\begin{array}{l}\text { Increased ratio of } \\
\text { tyrosine linked } \\
\text { O-glycosylated } A \beta \\
\text { peptides to } \\
\text { corresponding } \\
\text { unglycosylated } \\
\text { peptides [142]. }\end{array}$ & $\begin{array}{l}\text { AD patients }(n=6) \\
\text { versus non-AD } \\
\text { patients }(n=7) .\end{array}$ & $\begin{array}{c}\text { Patients not cognitively } \\
\text { assessed in detail. } \\
\text { Diagnosis based on } \\
\text { sensitive and specific CSF } \\
\text { biomarker detection of } \\
\text { pathological tau and A } \beta \\
\text { levels. }\end{array}$ \\
\hline
\end{tabular}


Table 1. Cont.

\begin{tabular}{|c|c|c|c|c|}
\hline Location & $\begin{array}{l}\text { Analysis } \\
\text { Method }\end{array}$ & Biomarker & Cohorts & Additional Comments \\
\hline Plasma & LC-MS/MS & $\begin{array}{c}\text { Decreased } \\
\text { N-glycosylation of } \\
\text { clusterin [181]. }\end{array}$ & $\begin{array}{l}\text { Mild/moderate AD } \\
\text { patients with high } \\
\text { hippocampal atrophy } \\
(n=14) \text { versus those } \\
\text { with low hippocampal } \\
\text { atrophy }(n=13) .\end{array}$ & $\begin{array}{c}\mathrm{N} \text {-glycans modified with } \\
\text { mannose, galactose, sialic } \\
\text { acid and GlcNAc. } \\
\text { Determined that decreased } \\
\text { glycans all present at a } \\
\text { common N-glycosylation } \\
\text { site on clusterin. }\end{array}$ \\
\hline CSF & $\begin{array}{l}\text { Lectin blotting, } \\
\text { isoelectric } \\
\text { focusing and MS }\end{array}$ & $\begin{array}{l}\text { Decreased sialylation } \\
\text { of transferrin [186]. }\end{array}$ & $\begin{array}{l}\text { Diagnosed probable } \\
\text { AD patients }(n=43) \\
\text { versus non-AD }(n=13) \\
\text { and non-demented } \\
\quad(n=32) \text { controls. }\end{array}$ & $\begin{array}{c}\text { Combined with } \\
\text { phosphorylated tau } \\
\text { detection, specificity and } \\
\text { sensitivity was } 88.4 \% \text { and } \\
92.3 \% \text {, respectively. CSF } \\
\text { transferrin levels did not } \\
\text { differ between groups. }\end{array}$ \\
\hline Serum & $\begin{array}{c}\text { Isoelectric } \\
\text { focusing and } \\
\text { immuno-blotting }\end{array}$ & $\begin{array}{l}\text { Increased penta- and } \\
\text { hexa-sialylation of } \\
\text { transferrin [187]. }\end{array}$ & $\begin{array}{l}\text { AD patients }(n=11) \\
\text { versus non-demented, } \\
\text { age-matched controls } \\
\quad(n=14) .\end{array}$ & \\
\hline CSF & Lectin blotting & $\begin{array}{c}\text { Increased } \\
\text { mannosylated glycans } \\
\text { on reelin [196]. }\end{array}$ & $\begin{array}{l}\text { AD patients }(n=11) \\
\text { versus non-demented, } \\
\text { age- and sex-matched } \\
\text { controls }(n=9) .\end{array}$ & $\begin{array}{l}\text { Combining two lectin } \\
\text { stains increased } \\
\text { discrimination of AD from } \\
\text { controls. } 10 \text { of } 11 \text { AD cases } \\
\text { were below an arbitrary } \\
\text { cutoff point, and } 7 \text { of } 9 \\
\text { controls were above this } \\
\text { cutoff. }\end{array}$ \\
\hline Plasma & LC-MS/MS & $\begin{array}{l}\text { Decreased complex, } \\
\text { galactosylated and } \\
\text { sialylated glycans on } \\
\text { IgG [204]. }\end{array}$ & $\begin{array}{l}\text { AD patients }(n=31) \\
\text { versus non-demented } \\
\text { controls }(n=26) .\end{array}$ & $\begin{array}{l}\text { One such bi-antennary, } \\
\text { complex, bi-galactosylated } \\
\text { glycan decreased in } \\
\text { females }(n=93) \text { steadily } \\
\text { prior to disease onset from } \\
\text { earlier to later stage cases, } \\
\text { but an inverse trend was } \\
\text { true for males ( } n=65) \text {. }\end{array}$ \\
\hline
\end{tabular}

Mass spectrometry, MS; Alzheimer's disease, AD; DNA sequencer-assisted, fluorophore-assisted carbohydrate electrophoresis, DSA-FACE; cerebrospinal fluid, CSF; liquid chromatography, LC; amyloid beta, A $\beta$; N-acetyl glucosamine, GlcNAc.

Author Contributions: Writing-Original Draft Preparation, P.R.; Writing-Review \& Editing, P.R., P.L.M., T.S., M.D.

Funding: This research was funded by the Institute of Technology Sligo President's Bursary fund. The APC was funded by the Institute of Technology Sligo President's Bursary fund.

Conflicts of Interest: The authors declare no conflicts of interest. The funders had no role in the design of the study; in the collection, analyses, or interpretation of data; in the writing of the manuscript, or in the decision to publish the results.

\section{References}

1. Morris, M.C. The role of nutrition in Alzheimer's disease: Epidemiological evidence. Eur. J. Neurol. 2009, 16, 1-7. [CrossRef] [PubMed]

2. World Health Organization. Dementia. Available online: http://www.who.int/en/news-room/fact-sheets/ detail/dementia (accessed on 1 March 2018).

3. Brookmeyer, R.; Johnson, E.; Ziegler-Graham, K.; Arrighi, H.M. Forecasting the global burden of Alzheimer's disease. Alzheimer's Dement. 2007, 3, 186-191. [CrossRef] [PubMed]

4. Alzheimer's Association. What Is Alzheimer's? Available online: https://www.alz.org/alzheimers_disease_ what_is_alzheimers.asp (accessed on 15 January 2018). 
5. Montgomery, W.; Goren, A.; Kahle-Wrobleski, K.; Nakamura, T.; Ueda, K. Detection, diagnosis, and treatment of Alzheimer's disease dementia stratified by severity as reported by caregivers in Japan. Neuropsychiatr. Dis. Treat. 2018, 14, 1843-1854. [CrossRef]

6. Musicco, M.; Palmer, K.; Salamone, G.; Lupo, F.; Perri, R.; Mosti, S.; Spalletta, G.; di Iulio, F.; Pettenati, C.; Cravello, L.; et al. Predictors of progression of cognitive decline in Alzheimer's disease: The role of vascular and sociodemographic factors. J. Neurol. 2009, 256, 1288-1295. [CrossRef] [PubMed]

7. Polanco, J.C.; Li, C.; Bodea, L.G.; Martinez-Marmol, R.; Meunier, F.A.; Gotz, J. Amyloid-beta and tau complexity-Towards improved biomarkers and targeted therapies. Nat. Rev. Neurol. 2018, 14, 22-39. [CrossRef]

8. Iqbal, K.; Liu, F.; Gong, C.X.; Grundke-Iqbal, I. Tau in Alzheimer Disease and Related Tauopathies. Curr. Alzheimer Res. 2010, 7, 656-664. [CrossRef]

9. Kadowaki, H.; Nishitoh, H.; Urano, F.; Sadamitsu, C.; Matsuzawa, A.; Takeda, K.; Masutani, H.; Yodoi, J.; Urano, Y.; Nagano, T.; et al. Amyloid beta induces neuronal cell death through ROS-mediated ASK1 activation. Cell Death Differ. 2005, 12, 19-24. [CrossRef]

10. Blennow, K.; de Leon, M.J.; Zetterberg, H. Alzheimer's disease. Lancet 2006, 368, 387-403. [CrossRef]

11. Waser, M.; Garn, H.; Schmidt, R.; Benke, T.; Dal-Bianco, P.; Ransmayr, G.; Schmidt, H.; Seiler, S.; Sanin, G.; Mayer, F.; et al. Quantifying synchrony patterns in the EEG of Alzheimer's patients with linear and non-linear connectivity markers. J. Neural Transm. 2016, 123, 297-316. [CrossRef]

12. Braak, H.; Braak, E. Neuropathological stageing of Alzheimer-related changes. Acta Neuropathol. 1991, 82, 239-259. [CrossRef] [PubMed]

13. Sheng, M.; Sabatini, B.; Südhof, T.C. Synapses and Alzheimer's disease. Cold Spring Harb. Perspect. Biol. 2012, 4, a005777. [CrossRef] [PubMed]

14. Mora-Bermúdez, F.; Badsha, F.; Kanton, S.; Camp, J.G.; Vernot, B.; Köhler, K.; Voigt, B.; Okita, K.; Maricic, T.; $\mathrm{He}, \mathrm{Z}$.; et al. Differences and similarities between human and chimpanzee neural progenitors during cerebral cortex development. ELife 2016, 5, e18683. [CrossRef] [PubMed]

15. Cheon, S. Hippocampus-dependent Task Improves the Cognitive Function after Ovariectomy in Rats. Osong Public Health Res. Perspect. 2017, 8, 227-234. [CrossRef] [PubMed]

16. Ridha, B.H.; Barnes, J.; Bartlett, J.W.; Godbolt, A.; Pepple, T.; Rossor, M.N.; Fox, N.C. Tracking atrophy progression in familial Alzheimer's disease: A serial MRI study. Lancet Neurol. 2006, 5, 828-834. [CrossRef]

17. Frisoni, G.B.; Fox, N.C.; Jack, C.R.; Scheltens, P.; Thompson, P.M. The clinical use of structural MRI in Alzheimer disease. Nat. Rev. Neurol. 2010, 6, 67-77. [CrossRef] [PubMed]

18. Lombardo, S.; Maskos, U. Role of the nicotinic acetylcholine receptor in Alzheimer's disease pathology and treatment. Neuropharmacology 2015, 96, 255-262. [CrossRef] [PubMed]

19. Yiannopoulou, K.G.; Papageorgiou, S.G. Current and future treatments for Alzheimer's disease. Ther. Adv. Neurol. Disord. 2013, 6, 19-33. [CrossRef]

20. Malik, G.A.; Robertson, N.P. Treatments in Alzheimer's disease. J. Neurol. 2017, 264, 416-418. [CrossRef]

21. De Strooper, B.; Vassar, R.; Golde, T. The secretases: Enzymes with therapeutic potential in Alzheimer disease. Nat. Rev. Neurol. 2010, 6, 99-107. [CrossRef]

22. Coimbra, J.R.M.; Marques, D.F.F.; Baptista, S.J.; Pereira, C.M.F.; Moreira, P.I.; Dinis, T.C.P.; Santos, A.E.; Salvador, J.A.R. Highlights in BACE1 Inhibitors for Alzheimer's Disease Treatment. Front. Chem. 2018, 6, 1-10. [CrossRef]

23. Salloway, S.; Sperling, R.; Gilman, S.; Fox, N.C.; Blennow, K.; Raskind, M.; Sabbagh, M.; Honig, L.S.; Doody, R.; van Dyck, C.H.; et al. A phase 2 multiple ascending dose trial of bapineuzumab in mild to moderate Alzheimer disease. Neurology 2009, 73, 2061-2070. [CrossRef] [PubMed]

24. Black, R.S.; Sperling, R.A.; Safirstein, B.; Motter, R.N.; Pallay, A.; Nichols, A.; Grundman, M. A single ascending dose study of bapineuzumab in patients with Alzheimer disease. Alzheimer Dis. Assoc. Disord. 2010, 24, 198-203. [CrossRef] [PubMed]

25. Wischik, C.M.; Staff, R.T.; Wischik, D.J.; Bentham, P.; Murray, A.D.; Storey, J.M.; Kook, K.A.; Harrington, C.R. Tau aggregation inhibitor therapy: An exploratory phase 2 study in mild or moderate Alzheimer's disease. J. Alzheimer's Dis. 2015, 44, 705-720. [CrossRef] [PubMed]

26. Lovestone, S.; Boada, M.; Dubois, B.; Hull, M.; Rinne, J.O.; Huppertz, H.J.; Calero, M.; Andres, M.V.; Gomez-Carrillo, B.; Leon, T.; et al. A phase II trial of tideglusib in Alzheimer's disease. J. Alzheimer's Dis. 2015, 45, 75-88. [CrossRef] [PubMed] 
27. Jiang, C.S.; Wang, Y.Y.; Song, J.T.; Yu, J.H. Acylphloroglucinols as kinase inhibitors from Sargassum nigrifoloides. J. Asian Nat. Prod. Res. 2018, 21, 619-626. [CrossRef] [PubMed]

28. Cummings, J.L.; Morstorf, T.; Zhong, K. Alzheimer's disease drug-development pipeline: Few candidates, frequent failures. Alzheimer's Res. Ther. 2014, 6, 37. [CrossRef] [PubMed]

29. Mehta, D.; Jackson, R.; Paul, G.; Shi, J.; Sabbagh, M. Why do trials for Alzheimer's disease drugs keep failing? A discontinued drug perspective for 2010-2015. Expert Opin. Investig. Drugs 2017, 26, 735-739. [CrossRef] [PubMed]

30. Farlow, M.; Anand, R.; Messina, J., Jr.; Hartman, R.; Veach, J. A 52-Week Study of the Efficacy of Rivastigmine in Patients with Mild to Moderately Severe Alzheimer's Disease. Eur. Neurol. 2000, 44, 236-241. [CrossRef] [PubMed]

31. Almkvist, O.; Darreh-Shori, T.; Stefanova, E.; Spiegel, R.; Nordberg, A. Preserved cognitive function after 12 months of treatment with rivastigmine in mild Alzheimer's disease in comparison with untreated AD and MCI patients. Eur. J. Neurol. 2004, 11, 253-261. [CrossRef] [PubMed]

32. Corder, E.H.; Saunders, A.M.; Strittmatter, W.J.; Schmechel, D.E.; Gaskell, P.C.; Small, G.W.; Roses, A.D.; Haines, J.L.; Pericak-Vance, M.A. Gene dose of apolipoprotein E type 4 allele and the risk of Alzheimer's disease in late onset families. Science 1993, 261, 921-923. [CrossRef] [PubMed]

33. Meraz-Ríos, M.A.; Franco-Bocanegra, D.; Toral Rios, D.; Campos-Peña, V. Early onset Alzheimer's disease and oxidative stress. Oxidative Med. Cell. Longev. 2014, 2014, 1-14. [CrossRef] [PubMed]

34. Sassi, C.; Guerreiro, R.; Gibbs, R.; Ding, J.; Lupton, M.K.; Troakes, C.; Lunnon, K.; Al-Sarraj, S.; Brown, K.S.; Medway, C.; et al. Exome sequencing identifies 2 novel presenilin 1 mutations (p. L166V and p. S230R) in British early-onset Alzheimer's disease. Neurobiol. Aging 2014, 35, 2422-e13. [CrossRef] [PubMed]

35. Salloway, S.; Correia, S. Alzheimer disease: Time to improve its diagnosis and treatment. Clevel. Clin. J. Med. 2009, 76, 49-58. [CrossRef] [PubMed]

36. Neugroschl, J.; Wang, S. Alzheimer's Disease: Diagnosis and Treatment Across the Spectrum of Disease Severity. Mt. Sinai J. Med. N. Y. 2011, 78, 596-612. [CrossRef] [PubMed]

37. Fox, N.C.; Schott, J.M. Imaging cerebral atrophy: Normal ageing to Alzheimer's disease. Lancet 2004, 363, 392-394. [CrossRef]

38. Szot, P. Common factors among Alzheimer's disease, Parkinson's disease, and epilepsy: Possible role of the noradrenergic nervous system. Epilepsia 2012, 53, 61-66. [CrossRef]

39. Cuttler, J.M.; Moore, E.R.; Hosfeld, V.D.; Nadolski, D.L. Treatment of Alzheimer Disease with CT Scans: A Case Report. Dose Response Int. J. 2016, 14, 1559325816640073. [CrossRef]

40. van de Pol, L.A.; Hensel, A.; van der Flier, W.M.; Visser, P.J.; Pijnenburg, Y.A.L.; Barkhof, F.; Gertz, H.J.; Scheltens, P. Hippocampal atrophy on MRI in frontotemporal lobar degeneration and Alzheimer's disease. J. Neurol. Neurosurg. Psychiatry 2006, 77, 439-442. [CrossRef]

41. Montoya, A.; Price, B.H.; Menear, M.; Lepage, M. Brain imaging and cognitive dysfunctions in Huntington's disease. J. Psychiatry Neurosci. 2006, 31, 21-29.

42. Cruz de Souza, L.; Chupin, M.; Bertoux, M.; Lehéricy, S.; Dubois, B.; Lamari, F.; Le Ber, I.; Bottlaender, M.; Colliot, O.; Sarazin, M. Is Hippocampal Volume a Good Marker to Differentiate Alzheimer's Disease from Frontotemporal Dementia? J. Alzheimer's Dis. 2013, 36, 57-66. [CrossRef]

43. Fodero, L.R.; Sáez-Valero, J.; Barquero, M.S.; Marcos, A.; McLean, C.A.; Small, D.H. Wheat germ agglutinin-binding glycoproteins are decreased in Alzheimer's disease cerebrospinal fluid. J. Neurochem. 2001, 79, 1022-1026. [CrossRef] [PubMed]

44. Schilling, L.P.; Zimmer, E.R.; Shin, M.; Leuzy, A.; Pascoal, T.A.; Benedet, A.L.; Borelli, W.V.; Palmini, A.; Gauthier, S.; Rosa-Neto, P. Imaging Alzheimer's disease pathophysiology with PET. Dement. Neuropsychol. 2016, 10, 79-90. [CrossRef] [PubMed]

45. Marcus, C.; Mena, E.; Subramaniam, R.M. Brain PET in the diagnosis of Alzheimer's disease. Clin. Nucl. Med. 2014, 39, e413-e426. [CrossRef] [PubMed]

46. Mosconi, L.; Berti, V.; Glodzik, L.; Pupi, A.; De Santi, S.; de Leon, M.J. Pre-Clinical Detection of Alzheimer's Disease Using FDG-PET, with or without Amyloid Imaging. J. Alzheimer's Dis. 2010, 20, 843-854. [CrossRef] [PubMed]

47. Huang, Y.; Mucke, L. Alzheimer Mechanisms and Therapeutic Strategies. Cell 2012, 148, $1204-1222$. [CrossRef] 
48. Rabinovici, G.D.; Jagust, W.J. Amyloid Imaging in Aging and Dementia: Testing the Amyloid Hypothesis In Vivo. Behav. Neurol. 2009, 21, 117-128. [CrossRef]

49. Okamura, N.; Harada, R.; Ishiki, A.; Kikuchi, A.; Nakamura, T.; Kudo, Y. The development and validation of tau PET tracers: Current status and future directions. Clin. Transl. Imaging 2018, 6, 305-316. [CrossRef]

50. Khan, T.; Alkon, D. Alzheimer's Disease Cerebrospinal Fluid and Neuroimaging Biomarkers: Diagnostic Accuracy and Relationship to Drug Efficacy. J. Alzheimer's Dis. 2015, 46, 817-836. [CrossRef]

51. Liu, L.; Xu, Y.-X.; Hirschberg, C.B. The role of nucleotide sugar transporters in development of eukaryotes. Semin. Cell Dev. Biol. 2010, 21, 600-608. [CrossRef]

52. Aebi, M. N-linked protein glycosylation in the ER. Biochim. Biophys. Acta 2013, 1833, 2430-2437. [CrossRef]

53. Sharma, A.; Vijayan, M. Influence of glycosidic linkage on the nature of carbohydrate binding in $\beta$-prism I fold lectins: An X-ray and molecular dynamics investigation on banana lectin-carbohydrate complexes. Glycobiology 2011, 21, 23-33. [CrossRef] [PubMed]

54. Lairson, L.; Henrissat, B.; Davies, G.J.; Withers, S. Glycosyltransferases: Structures, Functions, and Mechanisms. Annu. Rev. Biochem. 2008, 77, 521-555. [CrossRef] [PubMed]

55. Kwan, D.H. Chapter Two-Structure-Guided Directed Evolution of Glycosidases: A Case Study in Engineering a Blood Group Antigen-Cleaving Enzyme. In Methods in Enzymology; Imperiali, B., Ed.; Academic Press: New York, NY, USA, 2017; Volume 597, pp. 25-53.

56. An, H.J.; Froehlich, J.W.; Lebrilla, C.B. Determination of Glycosylation Sites and Site-specific Heterogeneity in Glycoproteins. Curr. Opin. Chem. Biol. 2009, 13, 421-426. [CrossRef] [PubMed]

57. Lu, Q.; Li, S.; Shao, F. Sweet Talk: Protein Glycosylation in Bacterial Interaction with the Host. Trends Microbiol. 2015, 23, 630-641. [CrossRef]

58. Jensen, P.H.; Kolarich, D.; Packer, N.H. Mucin-type O-glycosylation-Putting the pieces together. FEBS J. 2010, 277, 81-94. [CrossRef] [PubMed]

59. Apweiler, R.; Hermjakob, H.; Sharon, N. On the frequency of protein glycosylation, as deduced from analysis of the SWISS-PROT database. Biochim. Biophys. Acta 1999, 1473, 4-8. [CrossRef]

60. Kizuka, Y.; Kitazume, S.; Taniguchi, N. N-glycan and Alzheimer's disease. Biochim. Biophys. Acta 2017, 1861, 2447-2454. [CrossRef]

61. Schedin-Weiss, S.; Winblad, B.; Tjernberg, L.O. The role of protein glycosylation in Alzheimer disease. FEBS J. 2014, 281, 46-62. [CrossRef]

62. Frenkel-Pinter, M.; Stempler, S.; Tal-Mazaki, S.; Losev, Y.; Singh-Anand, A.; Escobar-Alvarez, D.; Lezmy, J.; Gazit, E.; Ruppin, E.; Segal, D. Altered protein glycosylation predicts Alzheimer's disease and modulates its pathology in disease model Drosophila. Neurobiol. Aging 2017, 56, 159-171. [CrossRef]

63. Taniguchi, N.; Takahashi, M.; Kizuka, Y.; Kitazume, S.; Shuvaev, V.V.; Ookawara, T.; Furuta, A. Glycation vs. glycosylation: A tale of two different chemistries and biology in Alzheimer's disease. Glycoconj. J. 2016, 33, 487-497. [CrossRef]

64. Lassen, P.S.; Thygesen, C.; Larsen, M.R.; Kempf, S.J. Understanding Alzheimer's disease by global quantification of protein phosphorylation and sialylated N-linked glycosylation profiles: A chance for new biomarkers in neuroproteomics? J. Proteom. 2017, 161, 11-25. [CrossRef] [PubMed]

65. Mohorko, E.; Glockshuber, R.; Aebi, M. Oligosaccharyltransferase: The central enzyme of N-linked protein glycosylation. J. Inherit. Metab. Dis. 2011, 34, 869-878. [CrossRef] [PubMed]

66. Higel, F.; Seidl, A.; Sörgel, F.; Friess, W. N-glycosylation heterogeneity and the influence on structure, function and pharmacokinetics of monoclonal antibodies and Fc fusion proteins. Eur. J. Pharm. Biopharm. 2016, 100, 94-100. [CrossRef] [PubMed]

67. Fisher, P.; Ungar, D. Bridging the Gap between Glycosylation and Vesicle Traffic. Front. Cell Dev. Biol. 2016, 4, 15. [CrossRef] [PubMed]

68. Roth, Z.; Yehezkel, G.; Khalaila, I. Identification and Quantification of Protein Glycosylation. Int. J. Carbohydr. Chem. 2012, 2012, 1-10. [CrossRef]

69. Chung, C.Y.; Majewska, N.I.; Wang, Q.; Paul, J.T.; Betenbaugh, M.J. SnapShot: N-Glycosylation Processing Pathways across Kingdoms. Cell 2017, 171, 258. [CrossRef]

70. Zhang, L.; Luo, S.; Zhang, B. Glycan analysis of therapeutic glycoproteins. MAbs 2016, 8, 205-215. [CrossRef]

71. Geyer, H.; Geyer, R. Strategies for analysis of glycoprotein glycosylation. Biochim. Biophys. Acta 2006, 1764, 1853-1869. [CrossRef] 
72. Tarentino, A.L.; Gomez, C.M.; Plummer, T.H. Deglycosylation of asparagine-linked glycans by peptide: N-glycosidase F. Biochemistry 1985, 24, 4665-4671. [CrossRef]

73. Mucha, E.; Stuckmann, A.; Marianski, M.; Struwe, W.B.; Meijer, G.; Pagel, K. In-depth structural analysis of glycans in the gas phase. Chem. Sci. 2019, 10, 1272-1284. [CrossRef]

74. Mechref, Y. Analysis of glycans derived from glycoconjugates by capillary electrophoresis-mass spectrometry. Electrophoresis 2011, 32, 3467-3481. [CrossRef] [PubMed]

75. Huang, Y.; Nie, Y.; Boyes, B.; Orlando, R. Resolving Isomeric Glycopeptide Glycoforms with Hydrophilic Interaction Chromatography (HILIC). J. Biomol. Tech. 2016, 27, 98-104. [CrossRef] [PubMed]

76. Bones, J.; McLoughlin, N.; Hilliard, M.; Wynne, K.; Karger, B.L.; Rudd, P.M. 2D-LC Analysis of BRP 3 Erythropoietin N-Glycosylation using Anion Exchange Fractionation and Hydrophilic Interaction UPLC Reveals Long Poly-N-Acetyl Lactosamine Extensions. Anal. Chem. 2011, 83, 4154-4162. [CrossRef] [PubMed]

77. Zhao, S.; Walsh, I.; Abrahams, J.L.; Royle, L.; Nguyen-Khuong, T.; Spencer, D.; Fernandes, D.L.; Packer, N.H.; Rudd, P.M.; Campbell, M.P. GlycoStore: A database of retention properties for glycan analysis. Bioinformatics 2018, 34, 3231-3232. [CrossRef] [PubMed]

78. Ahn, J.; Bones, J.; Yu, Y.Q.; Rudd, P.M.; Gilar, M. Separation of 2-aminobenzamide labeled glycans using hydrophilic interaction chromatography columns packed with $1.7 \mu \mathrm{m}$ sorbent. J. Chromatogr. B 2010, 878, 403-408. [CrossRef] [PubMed]

79. Grumbach, E.; Diehl, D.; D Neue, U. The application of novel $1.7 \mu$ m ethylene bridged hybrid particles for hydrophilic interaction chromatography. J. Sep. Sci. 2008, 31, 1511-1518. [CrossRef]

80. Wilson, I.D.; Nicholson, J.K.; Castro-Perez, J.; Granger, J.H.; Johnson, K.A.; Smith, B.W.; Plumb, R.S. High Resolution "Ultra Performance" Liquid Chromatography Coupled to oa-TOF Mass Spectrometry as a Tool for Differential Metabolic Pathway Profiling in Functional Genomic Studies. J. Proteome Res. 2005, 4, 591-598. [CrossRef]

81. Pu, Y.; Ridgeway, M.E.; Glaskin, R.S.; Park, M.A.; Costello, C.E.; Lin, C. Separation and Identification of Isomeric Glycans by Selected Accumulation-Trapped Ion Mobility Spectrometry-Electron Activated Dissociation Tandem Mass Spectrometry. Anal. Chem. 2016, 88, 3440-3443. [CrossRef]

82. Mauko, L.; Lacher, N.A.; Pelzing, M.; Nordborg, A.; Haddad, P.R.; Hilder, E.F. Comparison of ZIC-HILIC and graphitized carbon-based analytical approaches combined with exoglycosidase digestions for analysis of glycans from monoclonal antibodies. J. Chromatogr. B 2012, 911, 93-104. [CrossRef]

83. Gotz, L.; Abrahams, J.L.; Mariethoz, J.; Rudd, P.M.; Karlsson, N.G.; Packer, N.H.; Campbell, M.P.; Lisacek, F. GlycoDigest: A tool for the targeted use of exoglycosidase digestions in glycan structure determination. Bioinformatics 2014, 30, 3131-3133. [CrossRef]

84. Kobata, A. Exo- and endoglycosidases revisited. Proc. Jpn. Acad. Ser. B 2013, 89, 97-117. [CrossRef] [PubMed]

85. Marino, K.; Bones, J.; Kattla, J.J.; Rudd, P.M. A systematic approach to protein glycosylation analysis: A path through the maze. Nat. Chem. Biol. 2010, 6, 713-723. [CrossRef] [PubMed]

86. Silveyra, M.X.; Evin, G.; Montenegro, M.F.; Vidal, C.J.; Martínez, S.; Culvenor, J.G.; Sáez-Valero, J. Presenilin 1 Interacts with Acetylcholinesterase and Alters Its Enzymatic Activity and Glycosylation. Mol. Cell. Biol. 2008, 28, 2908-2919. [CrossRef] [PubMed]

87. Guevara, J.; Dilhuydy, H.; Espinosa, B.; Delacourte, A.; Quirion, R.; Mena, R.; Joanette, Y.; Zenteno, E.; Robitaille, Y. Coexistence of reactive plasticity and neurodegeneration in Alzheimer diseased brains. Histol. Histopathol. 2004, 19, 1075-1084. [CrossRef] [PubMed]

88. Belický, Š.; Katrlík, J.; Tkáč, J. Glycan and lectin biosensors. Essays Biochem. 2016, 60, 37-47. [CrossRef] [PubMed]

89. Zou, X.; Yoshida, M.; Nagai-Okatani, C.; Iwaki, J.; Matsuda, A.; Tan, B.; Hagiwara, K.; Sato, T.; Itakura, Y.; Noro, E.; et al. A standardized method for lectin microarray-based tissue glycome mapping. Sci. Rep. 2017, 7, 43560. [CrossRef] [PubMed]

90. Domínguez-Vega, E.; Tengattini, S.; Peintner, C.; van Angeren, J.; Temporini, C.; Haselberg, R.; Massolini, G.; Somsen, G.W. High-resolution glycoform profiling of intact therapeutic proteins by hydrophilic interaction chromatography-mass spectrometry. Talanta 2018, 184, 375-381. [CrossRef]

91. Nwosu, C.; Yau, H.K.; Becht, S. Assignment of Core versus Antenna Fucosylation Types in Protein N-Glycosylation via Procainamide Labeling and Tandem Mass Spectrometry. Anal. Chem. 2015, 87, 5905-5913. [CrossRef] 
92. Tsai, T.H.; Wang, M.; Di Poto, C.; Hu, Y.; Zhou, S.; Zhao, Y.; Varghese, R.S.; Luo, Y.; Tadesse, M.G.; Ziada, D.H.; et al. LC-MS profiling of N-Glycans derived from human serum samples for biomarker discovery in hepatocellular carcinoma. J. Proteome Res. 2014, 13, 4859-4868. [CrossRef]

93. Zhou, S.; Wooding, K.; Mechref, Y. Analysis of Permethylated Glycan by Liquid Chromatography (LC) and Mass Spectrometry (MS). Methods Mol. Biol. 2017, 1503, 83-96. [CrossRef]

94. Leymarie, N.; Zaia, J. Effective Use of Mass Spectrometry for Glycan and Glycopeptide Structural Analysis. Anal. Chem. 2012, 84, 3040-3048. [CrossRef] [PubMed]

95. Sumer-Bayraktar, Z.; Nguyen-Khuong, T.; Jayo, R.; Chen, D.D.; Ali, S.; Packer, N.H.; Thaysen-Andersen, M. Micro- and macroheterogeneity of N-glycosylation yields size and charge isoforms of human sex hormone binding globulin circulating in serum. Proteomics 2012, 12, 3315-3327. [CrossRef] [PubMed]

96. Walsh, I.; Nguyen-Khuong, T.; Wongtrakul-Kish, K.; Tay, S.J.; Chew, D.; Tasha, J.; Taron, C.; Rudd, P. GlycanAnalyzer: Software for Automated Interpretation of N-Glycan Profiles after Exoglycosidase Digestions. Bioinformatics 2018, 35, 688-690. [CrossRef] [PubMed]

97. Ioffe, E.; Stanley, P. Mice lacking N-acetylglucosaminyltransferase I activity die at mid-gestation, revealing an essential role for complex or hybrid N-linked carbohydrates. Proc. Natl. Acad. Sci. USA 1994, 91, 728-732. [CrossRef] [PubMed]

98. Marek, K.W.; Vijay, I.K.; Marth, J.D. A recessive deletion in the GlcNAc-1-phosphotransferase gene results in peri-implantation embryonic lethality. Glycobiology 1999, 9, 1263-1271. [CrossRef]

99. Helenius, A.; Aebi, M. Intracellular functions of N-linked glycans. Science 2001, 291, 2364-2369. [CrossRef] [PubMed]

100. Griffin, M.E.; Hsieh-Wilson, L.C. Glycan Engineering for Cell and Developmental Biology. Cell Chem. Biol. 2016, 23, 108-121. [CrossRef]

101. Zhao, Y.Y.; Takahashi, M.; Gu, J.G.; Miyoshi, E.; Matsumoto, A.; Kitazume, S.; Taniguchi, N. Functional roles of N-glycans in cell signaling and cell adhesion in cancer. Cancer Sci. 2008, 99, 1304-1310. [CrossRef]

102. Ding, N.; Nie, H.; Sun, X.; Sun, W.; Qu, Y.; Liu, X.; Yao, Y.; Liang, X.; Chen, C.C.; Li, Y. Human serum N-glycan profiles are age and sex dependent. Age Ageing 2011, 40, 568-575. [CrossRef]

103. Selman, M.H.; Derks, R.J.; Bondt, A.; Palmblad, M.; Schoenmaker, B.; Koeleman, C.A.; van de Geijn, F.E.; Dolhain, R.J.; Deelder, A.M.; Wuhrer, M. Fc specific IgG glycosylation profiling by robust nano-reverse phase HPLC-MS using a sheath-flow ESI sprayer interface. J. Proteom. 2012, 75, 1318-1329. [CrossRef]

104. Adamczyk, B.; Tharmalingam, T.; Rudd, P.M. Glycans as cancer biomarkers. Biochim. Biophys. Acta 2012, 1820, 1347-1353. [CrossRef] [PubMed]

105. Saldova, R.; Asadi Shehni, A.; Haakensen, V.D.; Steinfeld, I.; Hilliard, M.; Kifer, I.; Helland, A.; Yakhini, Z.; Borresen-Dale, A.L.; Rudd, P.M. Association of N-glycosylation with breast carcinoma and systemic features using high-resolution quantitative UPLC. J. Proteome Res. 2014, 13, 2314-2327. [CrossRef] [PubMed]

106. Bones, J.; Byrne, J.C.; O’Donoghue, N.; McManus, C.; Scaife, C.; Boissin, H.; Nastase, A.; Rudd, P.M. Glycomic and glycoproteomic analysis of serum from patients with stomach cancer reveals potential markers arising from host defense response mechanisms. J. Proteome Res. 2011, 10, 1246-1265. [CrossRef] [PubMed]

107. Block, T.M.; Comunale, M.A.; Lowman, M.; Steel, L.F.; Romano, P.R.; Fimmel, C.; Tennant, B.C.; London, W.T.; Evans, A.A.; Blumberg, B.S.; et al. Use of targeted glycoproteomics to identify serum glycoproteins that correlate with liver cancer in woodchucks and humans. Proc. Natl. Acad. Sci. USA 2005, 102, 779-784. [CrossRef] [PubMed]

108. Albrecht, S.; Unwin, L.; Muniyappa, M.; Rudd, P. Glycosylation as a marker for inflammatory arthritis. Cancer Biomark. 2014, 14, 17-28. [CrossRef] [PubMed]

109. Jaeken, J.; Peanne, R. What is new in CDG? J. Inherit. Metab. Dis. 2017, 40, 569-586. [CrossRef] [PubMed]

110. Butler, M.; Quelhas, D.; Critchley, A.J.; Carchon, H.; Hebestreit, H.F.; Hibbert, R.G.; Vilarinho, L.; Teles, E.; Matthijs, G.; Schollen, E.; et al. Detailed glycan analysis of serum glycoproteins of patients with congenital disorders of glycosylation indicates the specific defective glycan processing step and provides an insight into pathogenesis. Glycobiology 2003, 13, 601-622. [CrossRef] [PubMed]

111. Klein, A. Human total serum N-glycome. Adv. Clin. Chem. 2008, 46, 51-85.

112. Kizuka, Y.; Kitazume, S.; Fujinawa, R.; Saito, T.; Iwata, N.; Saido, T.C.; Nakano, M.; Yamaguchi, Y.; Hashimoto, Y.; Staufenbiel, M.; et al. An aberrant sugar modification of BACE1 blocks its lysosomal targeting in Alzheimer's disease. EMBO Mol. Med. 2015, 7, 175. [CrossRef] 
113. Cole, S.L.; Vassar, R. The Alzheimer's disease $\beta$-secretase enzyme, BACE1. Mol. Neurodegener. $2007,2,22$. [CrossRef]

114. Kizuka, Y.; Nakano, M.; Kitazume, S.; Saito, T.; Saido, T.C.; Taniguchi, N. Bisecting GlcNAc modification stabilizes BACE1 protein under oxidative stress conditions. Biochem. J. 2016, 473, 21-30. [CrossRef] [PubMed]

115. Tönnies, E.; Trushina, E. Oxidative Stress, Synaptic Dysfunction, and Alzheimer's Disease. J. Alzheimer's Dis. JAD 2017, 57, 1105-1121. [CrossRef]

116. Chun, Y.S.; Kwon, O.H.; Chung, S. O-GlcNAcylation of amyloid-beta precursor protein at threonine 576 residue regulates trafficking and processing. Biochem. Biophys. Res. Commun. 2017, 490, 486-491. [CrossRef] [PubMed]

117. Akasaka-Manya, K.; Endo, T.; Manya, H.; Kawamura, M.; Hisanaga, S.I.; Tsumoto, H.; Miura, Y.; Hatsuta, H.; Murayama, S.; Saito, Y.; et al. Excess APP O-glycosylation by GalNAc-T6 decreases A $\beta$ production. J. Biochem. 2016, 161, 99-111. [CrossRef] [PubMed]

118. Kitazume, S.; Tachida, Y.; Kato, M.; Yamaguchi, Y.; Honda, T.; Hashimoto, Y.; Wada, Y.; Saito, T.; Iwata, N.; Saido, T.; et al. Brain endothelial cells produce amyloid \{beta\} from amyloid precursor protein 770 and preferentially secrete the O-glycosylated form. J. Biol. Chem. 2010, 285, 40097-40103. [CrossRef] [PubMed]

119. Akasaka-Manya, K.; Manya, H.; Sakurai, Y.; Wojczyk, B.S.; Kozutsumi, Y.; Saito, Y.; Taniguchi, N.; Murayama, S.; Spitalnik, S.L.; Endo, T. Protective effect of N -glycan bisecting GlcNAc residues on $\beta$-amyloid production in Alzheimer's disease. Glycobiology 2010, 20, 99-106. [CrossRef] [PubMed]

120. Liu, F.; Zaidi, T.; Iqbal, K.; Grundke-Iqbal, I.; Merkle, R.K.; Gong, C.X. Role of glycosylation in hyperphosphorylation of tau in Alzheimer's disease. FEBS Lett. 2002, 512, 101-106. [CrossRef]

121. Sato, Y.; Naito, Y.; Grundke-Iqbal, I.; Iqbal, K.; Endo, T. Analysis of N-glycans of pathological tau: Possible occurrence of aberrant processing of tau in Alzheimer's disease. FEBS Lett. 2001, 496, 152-160. [CrossRef]

122. Crespo, C.; García-Mompó, C.; Sanchez-Mataredona, D.; Varea, E.; Castillo-Gómez, E.; Blasco-Ibáñez, J.M.; Nacher, J.; Gómez-Climent, M.Á.; Guirado, R.; Hernández, S.; et al. The Polysialylated Form of the Neural Cell Adhesion Molecule (PSA-NCAM) Is Expressed in a Subpopulation of Mature Cortical Interneurons Characterized by Reduced Structural Features and Connectivity. Cereb. Cortex 2010, 21, 1028-1041. [CrossRef]

123. Murray, H.C.; Low, V.F.; Swanson, M.E.; Dieriks, B.V.; Turner, C.; Faull, R.L.; Curtis, M.A. Distribution of PSA-NCAM in normal, Alzheimer's and Parkinson's disease human brain. Neuroscience 2016, 330, 359-375. [CrossRef]

124. Palmigiano, A.; Barone, R.; Sturiale, L.; Sanfilippo, C.; Bua, R.O.; Romeo, D.A.; Messina, A.; Capuana, M.L.; Maci, T.; Le Pira, F.; et al. CSF N-glycoproteomics for early diagnosis in Alzheimer's disease. J. Proteom. 2016, 131, 29-37. [CrossRef] [PubMed]

125. Henriksen, K.; O’Bryant, S.E.; Hampel, H.; Trojanowski, J.Q.; Montine, T.J.; Jeromin, A.; Blennow, K.; Lönneborg, A.; Wyss-Coray, T.; Soares, H.; et al. The future of blood-based biomarkers for Alzheimer's disease. Alzheimer's Dement. J. Alzheimer's Assoc. 2014, 10, 115-131. [CrossRef] [PubMed]

126. Wang, J.; Cheng, X.; Zeng, J.; Yuan, J.; Wang, Z.; Zhou, W.; Zhang, Y. LW-AFC Effects on N-glycan Profile in Senescence-Accelerated Mouse Prone 8 Strain, a Mouse Model of Alzheimer's Disease. Aging Dis. 2017, 8, 101-114. [CrossRef] [PubMed]

127. Gizaw, S.T.; Ohashi, T.; Tanaka, M.; Hinou, H.; Nishimura, S. Glycoblotting method allows for rapid and efficient glycome profiling of human Alzheimer's disease brain, serum and cerebrospinal fluid towards potential biomarker discovery. Biochim. Biophys. Acta 2016, 1860, 1716-1727. [CrossRef] [PubMed]

128. Barone, R.; Sturiale, L.; Palmigiano, A.; Zappia, M.; Garozzo, D. Glycomics of pediatric and adulthood diseases of the central nervous system. J. Proteom. 2012, 75, 5123-5139. [CrossRef] [PubMed]

129. Maguire, T.M.; Gillian, A.M.; O’Mahony, D.; Coughlan, C.M.; Dennihan, A.; Breen, K.C. A decrease in serum sialyltransferase levels in Alzheimer's disease. Neurobiol. Aging 1994, 15, 99-102. [CrossRef]

130. Bertram, L.; Lange, C.; Mullin, K.; Parkinson, M.; Hsiao, M.; Hogan, M.F.; Schjeide, B.M.M.; Hooli, B.; Divito, J.; Ionita, I.; et al. Genome-wide association analysis reveals putative Alzheimer's disease susceptibility loci in addition to APOE. Am. J. Hum. Genet. 2008, 83, 623-632. [CrossRef]

131. Vanhooren, V.; Desmyter, L.; Liu, X.E.; Cardelli, M.; Franceschi, C.; Federico, A.; Libert, C.; Laroy, W.; Dewaele, S.; Contreras, R.; et al. N-glycomic changes in serum proteins during human aging. Rejuvenation Res. 2007, 10, 521-531a. [CrossRef]

132. Chen, C.C.; Engelborghs, S.; Dewaele, S.; Le Bastard, N.; Martin, J.J.; Vanhooren, V.; Libert, C.; De Deyn, P.P. Altered serum glycomics in Alzheimer disease: A potential blood biomarker? Rejuvenation Res. 2010, 13, 439-444. [CrossRef] 
133. Martínez-Cairo, S.; Zenteno, E.; Guzmán, A.; Espinosa, B.; Guevara, J.; Slomianny, M.C.; Hernández, P. Characterization of an O-Glycosylated Plaque-Associated Protein from Alzheimer Disease Brain. J. Neuropathol. Exp. Neurol. 2003, 62, 34-41. [CrossRef]

134. Dos Santos, J.P.A.; Vizuete, A.; Hansen, F.; Biasibetti, R.; Goncalves, C.A. Early and Persistent O-GlcNAc Protein Modification in the Streptozotocin Model of Alzheimer's Disease. J. Alzheimer's Dis. 2018, 61, 237-249. [CrossRef] [PubMed]

135. Zhu, Y.; Shan, X.; Yuzwa, S.A.; Vocadlo, D.J. The emerging link between O-GlcNAc and Alzheimer disease. J. Biol. Chem. 2014, 289, 34472-34481. [CrossRef] [PubMed]

136. Forster, S.; Welleford, A.S.; Triplett, J.C.; Sultana, R.; Schmitz, B.; Butterfield, D.A. Increased O-GlcNAc levels correlate with decreased O-GlcNAcase levels in Alzheimer disease brain. Biochim. Biophys. Acta 2014, 1842, 1333-1339. [CrossRef] [PubMed]

137. Alfaro, J.F.; Gong, C.X.; Monroe, M.E.; Aldrich, J.T.; Clauss, T.R.W.; Purvine, S.O.; Wang, Z.; Camp, D.G., 2nd; Shabanowitz, J.; Stanley, P.; et al. Tandem mass spectrometry identifies many mouse brain O-GlcNAcylated proteins including EGF domain-specific O-GlcNAc transferase targets. Proc. Natl. Acad. Sci. USA 2012, 109, 7280-7285. [CrossRef] [PubMed]

138. Wang, S.; Yang, F.; Petyuk, V.A.; Shukla, A.K.; Monroe, M.E.; Gritsenko, M.A.; Rodland, K.D.; Smith, R.D.; Qian, W.J.; Gong, C.X.; et al. Quantitative proteomics identifies altered O-GlcNAcylation of structural, synaptic and memory-associated proteins in Alzheimer's disease. J. Pathol. 2017, 243, 78-88. [CrossRef] [PubMed]

139. Akan, I.; Olivier-Van Stichelen, S.; Bond, M.R.; Hanover, J.A. Nutrient-driven O-GlcNAc in proteostasis and neurodegeneration. J. Neurochem. 2018, 144, 7-34. [CrossRef] [PubMed]

140. Wani, W.Y.; Chatham, J.C.; Darley-Usmar, V.; McMahon, L.L.; Zhang, J. O-GlcNAcylation and neurodegeneration. Brain Res. Bull. 2017, 133, 80-87. [CrossRef] [PubMed]

141. Ramos-Martinez, I.; Martinez-Loustalot, P.; Lozano, L.; Issad, T.; Limon, D.; Diaz, A.; Perez-Torres, A.; Guevara, J.; Zenteno, E. Neuroinflammation induced by amyloid beta25-35 modifies mucin-type O-glycosylation in the rat's hippocampus. Neuropeptides 2018, 67, 56-62. [CrossRef]

142. Halim, A.; Brinkmalm, G.; Ruetschi, U.; Westman-Brinkmalm, A.; Portelius, E.; Zetterberg, H.; Blennow, K.; Larson, G.; Nilsson, J. Site-specific characterization of threonine, serine, and tyrosine glycosylations of amyloid precursor protein/amyloid beta-peptides in human cerebrospinal fluid. Proc. Natl. Acad. Sci. USA 2011, 108, 11848-11853. [CrossRef]

143. O'Brien, R.J.; Wong, P.C. Amyloid precursor protein processing and Alzheimer's disease. Annu. Rev. Neurosci. 2011, 34, 185-204. [CrossRef]

144. Mattson, M.P.; Cheng, B.; Culwell, A.R.; Esch, F.S.; Lieberburg, I.; Rydel, R.E. Evidence for excitoprotective and intraneuronal calcium-regulating roles for secreted forms of the $\beta$-amyloid precursor protein. Neuron 1993, 10, 243-254. [CrossRef]

145. Goodman, Y.; Mattson, M.P. Secreted Forms of $\beta$-Amyloid Precursor Protein Protect Hippocampal Neurons against Amyloid $\beta$-Peptide-Induced Oxidative Injury. Exp. Neurol. 1994, 128, 1-12. [CrossRef] [PubMed]

146. Haass, C.; Kaether, C.; Thinakaran, G.; Sisodia, S. Trafficking and proteolytic processing of APP. Cold Spring Harb. Perspect. Med. 2012, 2, a006270. [CrossRef] [PubMed]

147. Charlwood, J.; Dingwall, C.; Matico, R.; Hussain, I.; Johanson, K.; Moore, S.; Powell, D.J.; Skehel, J.M.; Ratcliffe, S.; Clarke, B.; et al. Characterization of the glycosylation profiles of Alzheimer's beta -secretase protein Asp-2 expressed in a variety of cell lines. J. Biol. Chem. 2001, 276, 16739-16748. [CrossRef] [PubMed]

148. Kitazume, S.; Tachida, Y.; Oka, R.; Nakagawa, K.; Takashima, S.; Lee, Y.C.; Hashimoto, Y. Screening a series of sialyltransferases for possible BACE1 substrates. Glycoconj. J. 2006, 23, 437-441. [CrossRef] [PubMed]

149. Kitazume, S.; Nakagawa, K.; Oka, R.; Tachida, Y.; Ogawa, K.; Luo, Y.; Citron, M.; Shitara, H.; Taya, C.;

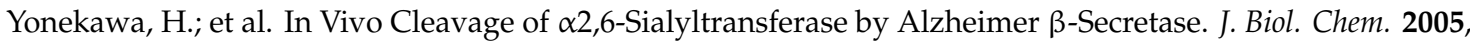
280, 8589-8595. [CrossRef] [PubMed]

150. Nakagawa, K.; Kitazume, S.; Oka, R.; Maruyama, K.; Saido, T.C.; Sato, Y.; Endo, T.; Hashimoto, Y. Sialylation enhances the secretion of neurotoxic amyloid-beta peptides. J. Neurochem. 2006, 96, 924-933. [CrossRef] [PubMed]

151. Sugimoto, I.; Futakawa, S.; Oka, R.; Ogawa, K.; Marth, J.D.; Miyoshi, E.; Taniguchi, N.; Hashimoto, Y.; Kitazume, S. Beta-galactoside alpha2,6-sialyltransferase I cleavage by BACE1 enhances the sialylation of soluble glycoproteins. A novel regulatory mechanism for alpha2,6-sialylation. J. Biol. Chem. 2007, 282, 34896-34903. [CrossRef] [PubMed] 
152. McFarlane, I.; Breen, K.C.; Di Giamberardino, L.; Moya, K.L. Inhibition of N-glycan processing alters axonal transport of synaptic glycoproteins in vivo. Neuroreport 2000, 11, 1543-1547. [CrossRef] [PubMed]

153. McFarlane, I.; Georgopoulou, N.; Coughlan, C.M.; Gillian, A.M.; Breen, K.C. The role of the protein glycosylation state in the control of cellular transport of the amyloid beta precursor protein. Neuroscience 1999, 90, 15-25. [CrossRef]

154. Tienari, P.J.; De Strooper, B.; Ikonen, E.; Simons, M.; Weidemann, A.; Czech, C.; Hartmann, T.; Ida, N.; Multhaup, G.; Masters, C.L.; et al. The beta-amyloid domain is essential for axonal sorting of amyloid precursor protein. EMBO J. 1996, 15, 5218-5229. [CrossRef] [PubMed]

155. Akasaka-Manya, K.; Manya, H.; Sakurai, Y.; Wojczyk, B.S.; Spitalnik, S.L.; Endo, T. Increased bisecting and core-fucosylated N-glycans on mutant human amyloid precursor proteins. Glycoconj. J. 2008, 25, 775-786. [CrossRef] [PubMed]

156. Kuhn, P.H.; Wang, H.; Dislich, B.; Colombo, A.; Zeitschel, U.; Ellwart, J.W.; Kremmer, E.; Roßner, S.; Lichtenthaler, S.F. ADAM10 is the physiologically relevant, constitutive $\alpha$-secretase of the amyloid precursor protein in primary neurons. EMBO J. 2010, 29, 3020-3032. [CrossRef] [PubMed]

157. Jorissen, E.; Prox, J.; Bernreuther, C.; Weber, S.; Schwanbeck, R.; Serneels, L.; Snellinx, A.; Craessaerts, K.; Thathiah, A.; Tesseur, I.; et al. The disintegrin/metalloproteinase ADAM10 is essential for the establishment of the brain cortex. J. Neurosci. 2010, 30, 4833-4844. [CrossRef] [PubMed]

158. Malinverno, M.; Carta, M.; Epis, R.; Marcello, E.; Verpelli, C.; Cattabeni, F.; Sala, C.; Mulle, C.; Di Luca, M.; Gardoni, F. Synaptic Localization and Activity of ADAM10 Regulate Excitatory Synapses through N-Cadherin Cleavage. J. Neurosci. 2010, 30, 16343. [CrossRef] [PubMed]

159. Colciaghi, F.; Borroni, B.; Pastorino, L.; Marcello, E.; Zimmermann, M.; Cattabeni, F.; Padovani, A.; Di Luca, M. $\alpha$-Secretase ADAM10 as well as $\alpha$ APPs is reduced in platelets and CSF of Alzheimer disease patients. Mol. Med. 2002, 8, 67-74. [CrossRef] [PubMed]

160. Escrevente, C.; Morais, V.A.; Keller, S.; Soares, C.M.; Altevogt, P.; Costa, J. Functional role of N-glycosylation from ADAM10 in processing, localization and activity of the enzyme. Biochim. Biophys. Acta 2008, 1780, 905-913. [CrossRef] [PubMed]

161. Arnold, C.S.; Johnson, G.V.W.; Cole, R.N.; Dong, D.L.Y.; Lee, M.; Hart, G.W. The Microtubule-associated Protein Tau Is Extensively Modified with O-linked N-acetylglucosamine. J. Biol. Chem. 1996, 271, 28741-28744. [CrossRef] [PubMed]

162. Kadavath, H.; Hofele, R.V.; Biernat, J.; Kumar, S.; Tepper, K.; Urlaub, H.; Mandelkow, E.; Zweckstetter, M. Tau stabilizes microtubules by binding at the interface between tubulin heterodimers. Proc. Natl. Acad. Sci. USA 2015, 112, 7501-7506. [CrossRef] [PubMed]

163. Grundke-Iqbal, I.; Iqbal, K.; Tung, Y.C.; Quinlan, M.; Wisniewski, H.M.; Binder, L.I. Abnormal phosphorylation of the microtubule-associated protein tau (tau) in Alzheimer cytoskeletal pathology. Proc. Natl. Acad. Sci. USA 1986, 83, 4913-4917. [CrossRef] [PubMed]

164. Šimić, G.; Babić Leko, M.; Wray, S.; Harrington, C.; Delalle, I.; Jovanov-Milošević, N.; Bažadona, D.; Buée, L.; de Silva, R.; Di Giovanni, G.; et al. Tau Protein Hyperphosphorylation and Aggregation in Alzheimer's Disease and Other Tauopathies, and Possible Neuroprotective Strategies. Biomolecules 2016, 6, 6. [CrossRef] [PubMed]

165. Lefebvre, T.; Ferreira, S.; Dupont-Wallois, L.; Bussière, T.; Dupire, M.J.; Delacourte, A.; Michalski, J.C.; Caillet-Boudin, M.L. Evidence of a balance between phosphorylation and O-GlcNAc glycosylation of Tau proteins-A role in nuclear localization. Biochim. Biophys. Acta 2003, 1619, 167-176. [CrossRef]

166. Hsu, Y.P.; Meng, X.; VanNieuwenhze, M.S. Chapter 1-Methods for visualization of peptidoglycan biosynthesis. In Methods in Microbiology; Harwood, C., Jensen, G.J., Eds.; Academic Press: Cambridge, MA, USA, 2016; Volume 43, pp. 3-48.

167. Saraswathy, N.; Ramalingam, P. 15-Phosphoproteomics. In Concepts and Techniques in Genomics and Proteomics; Woodhead Publishing: Cambridge, UK, 2012; pp. 203-211.

168. Liu, F.; Iqbal, K.; Grundke-Iqbal, I.; Hart, G.W.; Gong, C.X. O-GlcNAcylation regulates phosphorylation of tau: A mechanism involved in Alzheimer's disease. Proc. Natl. Acad. Sci. USA 2004, 101, 10804. [CrossRef] [PubMed]

169. Wang, J.Z.; Grundke-Iqbal, I.; Iqbal, K. Glycosylation of microtubule-associated protein tau: An abnormal posttranslational modification in Alzheimer's disease. Nat. Med. 1996, 2, 871. [CrossRef] [PubMed] 
170. Mandelkow, E.M.; Mandelkow, E. Biochemistry and cell biology of tau protein in neurofibrillary degeneration. Cold Spring Harb. Perspect. Med. 2012, 2, a006247. [CrossRef] [PubMed]

171. Stanley, P.; Taniguchi, N.; Aebi, N. Essentials of Glycobiology; Cold Spring Harbor Laboratory Press: Cold Spring Harbor, NY, USA, 2017.

172. De Strooper, B.; Iwatsubo, T.; Wolfe, M.S. Presenilins and $\gamma$-secretase: Structure, function, and role in Alzheimer Disease. Cold Spring Harb. Perspect. Med. 2012, 2, a006304. [CrossRef] [PubMed]

173. Yang, D.S.; Tandon, A.; Chen, F.; Yu, G.; Yu, H.; Arawaka, S.; Hasegawa, H.; Duthie, M.; Schmidt, S.D.; Ramabhadran, T.V.; et al. Mature glycosylation and trafficking of nicastrin modulate its binding to presenilins. J. Biol. Chem. 2002, 277, 28135-28142. [CrossRef]

174. Yu, G.; Nishimura, M.; Arawaka, S.; Levitan, D.; Zhang, L.; Tandon, A.; Song, Y.Q.; Rogaeva, E.; Chen, F.; Kawarai, T.; et al. Nicastrin modulates presenilin-mediated notch/glp-1 signal transduction and betaAPP processing. Nature 2000, 407, 48-54. [CrossRef]

175. Herreman, A.; Van Gassen, G.; Bentahir, M.; Nyabi, O.; Craessaerts, K.; Mueller, U.; Annaert, W.; De Strooper, B. Gamma-Secretase activity requires the presenilin-dependent trafficking of nicastrin through the Golgi apparatus but not its complex glycosylation. J. Cell Sci. 2003, 116, 1127-1136. [CrossRef]

176. Farquhar, M.J.; Gray, C.W.; Breen, K.C. The over-expression of the wild type or mutant forms of the presenilin-1 protein alters glycoprotein processing in a human neuroblastoma cell line. Neurosci. Lett. 2003, 346, 53-56. [CrossRef]

177. Bakulski, K.M.; Dolinoy, D.C.; Sartor, M.A.; Paulson, H.L.; Konen, J.R.; Lieberman, A.P.; Albin, R.L.; Hu, H.; Rozek, L.S. Genome-wide DNA methylation differences between late-onset Alzheimer's disease and cognitively normal controls in human frontal cortex. J. Alzheimer's Dis. 2012, 29, 571-588. [CrossRef] [PubMed]

178. Ullrich, S.; Münch, A.; Neumann, S.; Kremmer, E.; Tatzelt, J.; Lichtenthaler, S.F. The novel membrane protein TMEM59 modulates complex glycosylation, cell surface expression, and secretion of the amyloid precursor protein. J. Biol. Chem. 2010, 285, 20664-20674. [CrossRef] [PubMed]

179. Yu, J.T.; Tan, L. The role of clusterin in Alzheimer's disease: Pathways, pathogenesis, and therapy. Mol. Neurobiol. 2012, 45, 314-326. [CrossRef] [PubMed]

180. Gupta, V.B.; Hone, E.; Pedrini, S.; Doecke, J.; O’Bryant, S.; James, I.; Bush, A.I.; Rowe, C.C.; Villemagne, V.L.; Ames, D.; et al. Altered levels of blood proteins in Alzheimer's disease longitudinal study: Results from Australian Imaging Biomarkers Lifestyle Study of Ageing cohort. Alzheimer's Dement. 2017, 8, 60-72. [CrossRef] [PubMed]

181. Liang, H.C.; Russell, C.; Mitra, V.; Chung, R.; Hye, A.; Bazenet, C.; Lovestone, S.; Pike, I.; Ward, M. Glycosylation of Human Plasma Clusterin Yields a Novel Candidate Biomarker of Alzheimer's Disease. J. Proteome Res. 2015, 14, 5063-5076. [CrossRef] [PubMed]

182. Li, H.; Ruberu, K.; Munoz, S.S.; Jenner, A.M.; Spiro, A.; Zhao, H.; Rassart, E.; Sanchez, D.; Ganfornina, M.D.; Karl, T.; et al. Apolipoprotein D modulates amyloid pathology in APP/PS1 Alzheimer's disease mice. Neurobiol. Aging 2015, 36, 1820-1833. [CrossRef] [PubMed]

183. Li, H.; Ruberu, K.; Karl, T.; Garner, B. Cerebral Apolipoprotein-D Is Hypoglycosylated Compared to Peripheral Tissues and Is Variably Expressed in Mouse and Human Brain Regions. PLoS ONE 2016, 11, e0148238. [CrossRef]

184. Berg, D.; Youdim, M.B. Role of iron in neurodegenerative disorders. Top. Magn. Reson. Imaging 2006, 17, 5-17. [CrossRef] [PubMed]

185. Connor, J.R.; Menzies, S.L.; St Martin, S.M.; Mufson, E.J. A histochemical study of iron, transferrin, and ferritin in Alzheimer's diseased brains. J. Neurosci. Res. 1992, 31, 75-83. [CrossRef] [PubMed]

186. Taniguchi, M.; Okayama, Y.; Hashimoto, Y.; Kitaura, M.; Jimbo, D.; Wakutani, Y.; Wada-Isoe, K.; Nakashima, K.; Akatsu, H.; Furukawa, K.; et al. Sugar chains of cerebrospinal fluid transferrin as a new biological marker of Alzheimer's disease. Dement. Geriatr. Cogn. Disord. 2008, 26, 117-122. [CrossRef]

187. van Rensburg, S.J.; Berman, P.; Potocnik, F.; MacGregor, P.; Hon, D.; de Villiers, N. 5- and 6-glycosylation of transferrin in patients with Alzheimer's disease. Metab. Brain Dis. 2004, 19, 89-96. [CrossRef] [PubMed]

188. Atri, A.; Sherman, S.; Norman, K.A.; Kirchhoff, B.A.; Nicolas, M.M.; Greicius, M.D.; Cramer, S.C.; Breiter, H.C.; Hasselmo, M.E.; Stern, C.E. Blockade of central cholinergic receptors impairs new learning and increases proactive interference in a word paired-associate memory task. Behav. Neurosci. 2004, 118, 223-236. [CrossRef] [PubMed] 
189. Kihara, T.; Shimohama, S. Alzheimer's disease and acetylcholine receptors. Acta Neurobiologiae Experimentalis 2004, 64, 99-105. [PubMed]

190. Sáez-Valero, J.; de Ceballos, M.A.L.; Small, D.H.; de Felipe, C. Changes in molecular isoform distribution of acetylcholinesterase in rat cortex and cerebrospinal fluid after intracerebroventricular administration of amyloid $\beta$-peptide. Neurosci. Lett. 2002, 325, 199-202. [CrossRef]

191. Fodero, L.R.; Saez-Valero, J.; McLean, C.A.; Martins, R.N.; Beyreuther, K.; Masters, C.L.; Robertson, T.A.; Small, D.H. Altered glycosylation of acetylcholinesterase in APP (SW) Tg2576 transgenic mice occurs prior to amyloid plaque deposition. J. Neurochem. 2002, 81, 441-448. [CrossRef] [PubMed]

192. Saez-Valero, J.; Fodero, L.R.; Sjögren, M.; Andreasen, N.; Amici, S.; Gallai, V.; Vanderstichele, H.; Vanmechelen, E.; Parnetti, L.; Blennow, K.; et al. Glycosylation of acetylcholinesterase and butyrylcholinesterase changes as a function of the duration of Alzheimer's disease. J. Neurosci. Res. 2003, 72, 520-526. [CrossRef] [PubMed]

193. Durakoglugil, M.S.; Chen, Y.; White, C.L.; Kavalali, E.T.; Herz, J. Reelin signaling antagonizes $\beta$-amyloid at the synapse. Proc. Natl. Acad. Sci. USA 2009, 106, 15938-15943. [CrossRef] [PubMed]

194. Arnaud, L.; Ballif, B.A.; Cooper, J.A. Regulation of Protein Tyrosine Kinase Signaling by Substrate Degradation during Brain Development. Mol. Cell. Biol. 2003, 23, 9293-9302. [CrossRef]

195. Qiu, S.; Zhao, L.F.; Korwek, K.M.; Weeber, E.J. Differential reelin-induced enhancement of NMDA and AMPA receptor activity in the adult hippocampus. J. Neurosci. 2006, 26, 12943-12955. [CrossRef] [PubMed]

196. Botella-López, A.; Burgaya, F.; Gavín, R.; García-Ayllón, M.S.; Gómez-Tortosa, E.; Peña-Casanova, J.; Ureña, J.M.; Del Río, J.A.; Blesa, R.; Soriano, E.; et al. Reelin expression and glycosylation patterns are altered in Alzheimer's disease. Proc. Natl. Acad. Sci. USA 2006, 103, 5573-5578. [CrossRef] [PubMed]

197. Bayes-Genis, A.; Barallat, J.; Richards, A.M. A Test in Context: Neprilysin: Function, Inhibition, and Biomarker. J. Am. Coll. Cardiol. 2016, 68, 639-653. [CrossRef]

198. Iwata, N.; Tsubuki, S.; Takaki, Y.; Watanabe, K.; Sekiguchi, M.; Hosoki, E.; Kawashima-Morishima, M.; Lee, H.J.; Hama, E.; Sekine-Aizawa, Y.; et al. Identification of the major Abeta1-42-degrading catabolic pathway in brain parenchyma: Suppression leads to biochemical and pathological deposition. Nat. Med. 2000, 6, 143-150. [CrossRef] [PubMed]

199. Zhang, H.; Liu, D.; Wang, Y.; Huang, H.; Zhao, Y.; Zhou, H. Meta-analysis of expression and function of neprilysin in Alzheimer's disease. Neurosci. Lett. 2017, 657, 69-76. [CrossRef]

200. Lafrance, M.H.; Vézina, C.; Wang, Q.; Boileau, G.; Crine, P.; Lemay, G. Role of glycosylation in transport and enzymic activity of neutral endopeptidase-24.11. Biochem. J. 1994, 302, 451. [CrossRef] [PubMed]

201. Sato, B.; Katagiri, Y.U.; Iijima, K.; Yamada, H.; Ito, S.; Kawasaki, N.; Okita, H.; Fujimoto, J.; Kiyokawa, N. The human CD10 lacking an N-glycan at Asn (628) is deficient in surface expression and neutral endopeptidase activity. Biochim. Biophys. Acta 2012, 1820, 1715-1723. [CrossRef] [PubMed]

202. Jiang, T.; Yu, J.T.; Zhu, X.C.; Tan, L. TREM2 in Alzheimer's disease. Mol. Neurobiol. 2013, 48, 180-185. [CrossRef] [PubMed]

203. Park, J.S.; Ji, I.J.; Kim, D.H.; An, H.J.; Yoon, S.Y. The Alzheimer's Disease-Associated R47H Variant of TREM2 Has an Altered Glycosylation Pattern and Protein Stability. Front. Neurosci. 2016, 10, 618. [CrossRef] [PubMed]

204. Lundstrom, S.L.; Yang, H.; Lyutvinskiy, Y.; Rutishauser, D.; Herukka, S.K.; Soininen, H.; Zubarev, R.A. Blood plasma IgG Fc glycans are significantly altered in Alzheimer's disease and progressive mild cognitive impairment. J. Alzheimer's Dis. 2014, 38, 567-579. [CrossRef]

205. Wyss-Coray, T.; Rogers, J. Inflammation in Alzheimer disease-a brief review of the basic science and clinical literature. Cold Spring Harb. Perspect. Med. 2012, 2, a006346. [CrossRef]

206. Kaneko, Y.; Nimmerjahn, F.; Ravetch, J.V. Anti-inflammatory activity of immunoglobulin G resulting from Fc sialylation. Science 2006, 313, 670-673. [CrossRef]

207. Leeman, M.; Choi, J.; Hansson, S.; Storm, M.U.; Nilsson, L. Proteins and antibodies in serum, plasma, and whole blood-size characterization using asymmetrical flow field-flow fractionation (AF4). Anal. Bioanal. Chem. 2018, 410, 4867-4873. [CrossRef] [PubMed]

(C) 2019 by the authors. Licensee MDPI, Basel, Switzerland. This article is an open access article distributed under the terms and conditions of the Creative Commons Attribution (CC BY) license (http://creativecommons.org/licenses/by/4.0/). 